\title{
2. Der Stringansatz
}

\subsection{Perturbative Stringtheorien: Gravitation, Supersymmetrie und höhere Dimensionalität}

Der Stringansatz ${ }^{32}$, so unvollständig er in mancher Hinsicht bisher auch sein sollte, ist zur Zeit der am weitesten ausgearbeitete Versuch einer das Vereinheitlichungsprogramm der Physik abschliessenden gemeinsamen Beschreibung aller Wechselwirkungen einschliesslich der Gravitation. Er erweitert die perturbativen Prozeduren der Quantenfeldtheorien von punktförmigen Entitäten ("Punktteilchen" als den Feldquanten der entsprechenden Materie- und Wechselwirkungsfelder) zu eindimensional ausgedehnten Objekten - den Strings - und ihren quantenmechanischen (Schwingungsund Bewegungs-) Zuständen. ${ }^{33}$

Worin besteht aber der Vorteil dieses Übergangs? Wieso vollzieht man für eine Vereinigung aller Wechselwirkungen einschliesslich der Gravitation gerade einen Übergang zur Quantenmechanik eindimensional ausgedehnter Objekten? Dass eine Vereinigung aller Wechselwirkungen sich im Rahmen einer Quantenfeldtheorie, die von Punktobjekten als den Anregungszustän-

32 Systematische Einführungen in den Stringansatz bieten etwa Lüst / Theisen (1989), Hatfield (1992), Kaku (1999), Polchinski (1994) (1999) (2000) (2000a) sowie Zwiebach (2004). Einen Überblick über die Literatur zum Stringansatz gibt Marolf (2003).

33 Im klassischen Bild entspricht dies einem Übergang von der eindimensionalen Weltlinie (bzw. Trajektorie) eines Punktteilchens zum zweidimensionalen Weltblatt eines String. Die klassische Stringdynamik wird dann unter Berücksichtigung der Lorentz-Invarianz der Speziellen Relativitätstheorie quantisiert. So erhält man eine relativistische Quantentheorie der Dynamik eindimensional-ausgedehnter Objekte, um die es im folgenden erst einmal gehen wird. Im Rahmen einer zweiten Quantisierung sollte diese sich dann schliesslich zu einer Quantenfeldtheorie der Strings ("String Field Theory") erweitern lassen. Dass es hiermit letztendlich Probleme gibt und der formale Übergang von der Darstellung der Stringdynamik in der ersten Quantisierung zu der in der zweiten Quantisierung nicht ohne weiteres zu den gewünschten Ergebnissen führt, wird in Kap. 4.1. zu erörtern sein. 
den der entsprechenden Felder handelt, offensichtlich nicht erreichten lässt, zumindest wenn man störungstheoretische Prozeduren zum Einsatz bringt, haben die bisherigen Versuche in diese Richtung und die bei diesen auftretenden nicht-renormierbaren Divergenzen überzeugend gezeigt. Wieso geht man aber von eindimensionalen und nicht gleich von zwei-, drei- oder höherdimensionalen Grundentitäten und ihrer Dynamik aus? - Scheinbar aus gutem Grund: Höherdimensionale Grundelemente führen, zumindest im perturbativen Ansatz, ${ }^{34}$ wiederum zu unkontrollierbaren Divergenzen, die auf die inneren Freiheitsgrade dieser Grundelemente zurückgehen:

"One natural question is, why one-dimensional objects and not twodimensional or higher? For this at least there is a simple answer. Extended objects have an infinite number of internal degrees of freedom (the Fourier modes describing their shape). Spreading out point particles into extended objects softens the spacetime divergences but introduces potential new divergences from the internal degrees of freedom. The latter grow worse as the dimension of the object increases, and the one-dimensional case is the only one for which both the spacetime and internal behavior is under control." (Polchinski (1996) 6f)

Eindimensional ausgedehnte Grundelemente scheinen gerade den Vorteil zu haben, sowohl die raumzeitlichen Divergenzen von Theorien, die von punktförmigen Entitäten ausgehen, als auch die in den internen Freiheitsgraden begründeten Divergenzen von Theorien mit höherdimensionalen Grundelementen zu vermeiden. Sie scheinen diesbezüglich den idealen Kompromiss darzustellen.

Im Stringansatz gibt es im Gegensatz zu den Quantenfeldtheorien keine Wechselwirkungspunkte. Da die Strings sich (im klassischen Bild) nicht auf eindimensionalen Weltlinien, sondern auf zweidimensionalen Weltblättern bewegen, treten gerade nicht die Wechselwirkungsvertices auf, die zu den Divergenzen innerhalb der Quantenfeldtheorien führen und den Singularitäten in den Feynman-Diagrammen entsprechen. Die Weltblätter der Stringdynamik verbinden sich vielmehr in der Darstellung der Feyn-

34 Die im Verlauf der Entwicklung des Stringansatzes zutagetretende Einsicht, dass auch höherdimensionale Entitäten eine Rolle spielen, ergibt sich dann auch konsequenterweise erst im nicht-störungstheoretisch erfassbaren Bereich der Stringdynamik. Vgl. Kap. 2.3. und 2.4. 
man-Diagramme zu räumlich ausgedehnten, singularitätsfreien Strukturen mit unterschiedlicher Topologie:

"The string 'Feynman rules' are very different, and cannot even be approximated by particle QFT. String theory is therefore more than simply combining infinitely many particle fields, and it is this what makes a crucial difference." (Lerche (2000) 16)

Die in den Quantenfeldtheorien für steigende Energien und kleiner werdende Abstände typischen Divergenzen ${ }^{35}$ werden, wie man annimmt, im Rahmen des Stringansatzes dadurch vermieden, dass es für den String eine minimale Ausdehnung gibt. Die Grösse des String wächst für steigende Energien und kleiner werdende Wechselwirkungsabstände infolge der Unbestimmtheitsrelation, so dass sich der räumliche Wechselwirkungsbereich ausdehnt. ${ }^{36}$ Anschaulich lassen sich die Wechselwirkungszonen der Strings als räumlich verschmiert betrachten. Die für die verschiedenen Wechselwirkungen im quantenfeldtheoretischen Ansatz auftretenden Divergenzen, die für den Fall der Gravitation sogar nicht-renormierbar sind, löschen sich, wie man vermutet, gerade gegenseitig aus, so dass am Ende ein finiter Wert übrigbleibt. Die resultierende Theorie müsste dann nicht einmal renormiert werden, was für eine fundamentale Theorie unabdingbar ist, da eine Renormierung immer empirisch zu bestimmende, freie Parameter ins Spiel bringt, die wiederum auf einer fundamentaleren Ebene zu erklären wären. Die Notwendigkeit der Renormierung zeigt also gerade, dass eine Theorie nicht fundamental sein kann. Insofern hat der Stringansatz, wenn er als fundamentale Theorie in Frage kommen soll, überhaupt nur die Perspektive, ohne Renormierung auszukommen. Er muss entweder zu einer finiten Theorie führen, die keiner Renormierung bedarf, oder er wäre als fundamentale Theorie ohne Erfolgsaussichten. Man weiss ohnehin inzwischen, dass eine Theorie der Quantengravitation notwendigerweise entweder finit oder nicht-renormierbar ist:

"[...] it can be shown that theories which include gravity are either finite or non-renormalizable [...]." (Hawking (1980) 18f)

35 Gerade für hohe Energien werden die Divergenzen im Rahmen einer quantenfeldtheoretischen Behandlung der Gravitation infolge der Selbstwechselwirkung der Gravitonen unkontrollierbar.

36 Besser verstehen lässt sich dies im Rahmen der T-Dualität. Siehe Kap. 2.3. 
Aber Nachweise für die Divergenzfreiheit der Stringtheorien gibt es bisher nur bis zur zweiten störungstheoretischen Ordnung. ${ }^{37}$ Es lässt sich jedoch immerhin plausibel machen, dass die Divergenzfreiheit auch für die höheren Ordnungen gilt, was sogar von Vertretern von Konkurrenzansätzen bestätigt wird:

"[...] it is widely believed that the perturbation theory is finite to all orders; it does not even have to be renormalized." (Ashtekar (2005) 7)

Ein weiterer Vorteil des Stringansatzes besteht nach Ansicht seiner Vertreter in der mit ihm einhergehenden Reduzierung von Kontingenz. Theorien, die von punktförmigen Entitäten ausgehen, lassen sich in beliebiger Weise, für beliebige Symmetriegruppen und eine beliebige Zahl von Raumzeitdimensionen, mit beliebigen freien Parametern formulieren. Für den Stringansatz hingegen haben sich die internen Festlegungen als so einschränkend erwiesen, dass es lange Zeit als sehr schwierig galt, überhaupt eine konsistente Theorie $\mathrm{zu}$ formulieren. ${ }^{38}$ Die Ursache dafür liegt darin begründet, dass sich für Punktentitäten mit ihren eindimensionalen Trajektorien (Weltlinien) beliebige Wechselwirkungen formulieren lassen. Die Weltblätter der Stringdynamik liefern als Riemannsche Mannigfaltigkeiten hingegen sehr restriktive Festlegungen für die möglichen Wechselwirkungen von Strings:

"One of the crucial reasons why there are so many point particle actions (and so few string actions) is the difference between graphs and manifolds. The nontrivial restrictions placed on manifolds severely restrict the number of consistent string theories." (Kaku (1999) 53)

Dies alles liefert aber noch nicht die Antwort auf die Frage, wieso der Stringansatz überhaupt als vielversprechender Anwärter für eine umfassende nomologische Vereinigung aller Wechselwirkungen gilt. Die Antwort auf diese Frage hat sich in höchst kurioser und zufälliger Weise im Rahmen eines nur wenig geradlinigen historischen Entdeckungs- und Entwicklungsganges ergeben. Von diesen historischen Irrwegen soll erst spä-

37 Bis dahin sind sogar die alten Supergravity-Theorien divergenzfrei, von denen in Kap. 2.3. die Rede sein wird.

38 Die Kontingenzproblematik wird ausführlichst in Kap. 5. zu erörtern sein. 
ter die Rede sein. ${ }^{39}$ Die kurze Antwort lautet: Der Stringansatz schliesst in seiner Beschreibung notwendigerweise masselose Spin-2-Bosonen ein, die infolge ihres Verhaltens als Gravitonen interpretiert werden können. Der Stringansatz reproduziert damit nicht zuletzt die Allgemeine Relativitätstheorie als Niederenergienäherung. Wie es dazu kommt, ist eine Frage, die eine Erörterung der formalen Konzeption des Stringansatzes erfordert.

\section{Die formale Konzeption}

Der klassische String ist ein eindimensional-ausgedehntes Objekt, dessen Dynamik auf einem d-dimensionalen Minkowski-Raum erfasst wird. ${ }^{40}$ Das zweidimensionale Weltblatt der klassischen Stringbewegung auf diesem ddimensionalen Minkowski-Raum wird durch die von 0 bis $2 \pi$ laufenden internen Stringkoordinaten $\sigma$ und die Eigenzeit $\tau$ beschrieben. Die Einbettung des Weltblatts in den d-dimensionalen Minkowski-Raum wird durch d Koordinaten-Funktionen $\mathrm{X}^{\mu}(\sigma, \tau)$ erfasst. Diese d Funktionen lassen sich formal als Felder einer zweidimensionalen Quantenfeldtheorie ansehen.

Unter Berücksichtigung der Stringspannung ${ }^{41}$ bzw. der Masse oder Energie pro Längeneinheit, lässt sich eine klassische Wirkungsfunktion ${ }^{42}$ für den String formulieren, die im wesentlichen der Fläche des Weltblattes des String entspricht. Nach einer geeigneten Transformation zeigt diese Wirkungsfunktion Symmetrieeigenschaften, die zu einer zweidimensionalen klassischen konformen Feldtheorie gehören. Die konforme Invarianz entspricht der Tatsache, dass eine Umbenennung der Koordinaten $\sigma$ auf dem Weltblatt des String die physikalischen Zustände nicht verändert.

39 Dieser historische Entwicklungsgang wird in Kap. 4.1. genauer zu beleuchten sein.

$40 \quad$ Formal ist dieser "target space" auf gekrümmte Mannigfaltigkeiten erweiterbar. Siehe Sanchez (2003).

41 Die Stringspannung ist eine Konstante. Sie ist umgekehrt proportional zum Quadrat einer für die Stringtheorien grundlegenden Längeneinheit.

42 Für den einfachen bosonischen String ist dies die sogenannte Nambu-GotoWirkung. 
Es gibt zwei verschiedene Stringtopologien: offene und geschlossene Strings. Für geschlossene Strings gilt: $X^{\mu}(\sigma+2 \pi, \tau)=X^{\mu}(\sigma, \tau)$. Kein Punkt des geschlossenen String ist topologisch ausgezeichnet. Daher gibt es auch keine Möglichkeit für fixierte Ladungen ohne Symmetriebrechung. Offene Strings hingegen können an ihren Enden Ladungen ${ }^{43}$ tragen, die als Quellen der entsprechenden Felder wirksam werden. ${ }^{44}$

Ebenso gibt es zwei verschiedene Bewegungsformen für den klassischen String, sowohl für den offenen, als auch für den geschlossenen: die Translationsbewegung und die Oszillation. Für letztere sind rechtsorientierte (holomorphe) und linksorientierte (antiholomorphe) Schwingungen zu berücksichtigen.

\section{Quantisierung und Stringzustände}

Für die Quantisierung des String geht man nach gewöhnlichen quantenmechanischen Prozeduren vor. Man definiert Operatoren für die klassischen Grössen, die Kommutatorrelationen gehorchen, und entwickelt nach holomorphen und antiholomorphen Schwingungsmodi. ${ }^{45}$

43 Diese Ladungen sind hier erst einmal als Verallgemeinerung elektrischer Ladungen zu verstehen.

44 Die Ladungen lassen sich formal per Chan-Paton-Verfahren an die Enden anfügen:

"For the open superstring it is possible to introduce gauge symmetries using the

Chan-Paton procedure: we attach charges to the endpoints of the string." (Alva-

rez-Gaumé / Vázquez-Mozo (1992) 111)

"In the open string the gauge charges are carried by the Chan-Paton degrees of

freedom at the endpoints. In the closed string the charges are carried by fields

that move along the string." (Polchinski (2000a) 59)

Die Anfügung von Ladungen im Chan-Paton-Verfahren lässt sich jedoch nicht aus der Theorie heraus dynamisch begründen, sondern entspricht einer Ad-hoc-Prozedur, um mathematische Anomalien zu vermeiden:

"The Chan-Paton version of gauge string has the obvious disadvantage that the charged fields [...] are not an intrinsic part of the theory." (O'Raifeartaigh / Straumann (2000) 17)

45 Für die Quantisierung gibt es, zumindest im Rahmen der alten bosonische Stringtheorie und der alten Neveu-Schwarz-Ramond-Formulierung des Superstringansatzes diverse Optionen. (Vgl. Kaku (1999), Kap. 2. und 3.5.) Diese unterscheiden 
"[...] string theory is easy to quantize because its Hamiltonian is quadratic in the string variables. Simple harmonic oscillators can be used to quantize the theory." (Kaku (1999) 99)

Nach der Quantisierung eines klassischen relativistischen Strings ohne interne Struktur auf einer flachen Raumzeit ergeben sich Schwingungszustände mit unterschiedlicher Masse und Spin. Neben in erster Näherung masselosen Zuständen gibt es eine unendliche Serie von Zuständen mit

sich vor allem darin, inwiefern in ihnen die Lorentz-Invarianz, also die Kompatibilität mit der Speziellen Relativitätstheorie, und die quantenmechanische Unitarität der Dynamik direkt berücksichtigt werden oder erst im Nachhinein einfliessen:

Die Gupta-Bleuler-Quantisierung (auch als "alte kovariante Quantisierung" bezeichnet) mit ihrer manifesten Lorentz-Invarianz infolge einer konformen Eichung bzw. der konformen Transformationsinvarianz führt zu einer Darstellung der Theorie in Form freier Felder. Dieser einfache Quantisierungsansatz ist jedoch nicht unitär; es treten "Geist"-Zustände mit negativer Wahrscheinlichkeit auf, die in einem aufwendigen Verfahren ausgeschlossen werden müssen. Dieses Ausschlussverfahren entspricht der noch zu erörternden Virasoro-Algebra und führt schliesslich zur ebenfalls noch zu erörternden Festlegung der Dimensionszahl:

"The price we have to pay for this simplicity, however, is that we must impose the

Virasoro constraints directly onto the Hilbert space to eliminate ghosts." (Kaku (1999) 90)

Die Lichtkegel-Quantisierung verfügt über manifeste Unitarität, dafür aber nicht über eine manifeste Lorentz-Invarianz. Dies macht wiederum Einzelüberprüfungen erforderlich, die für Strings recht kompliziert ausfallen und ebenso zur Festlegung der Dimensionszahl führen:

"The great advantage of the light cone gauge is that the Virasoro constraints have been explicitly solved, so there is no need to impose them on states. [...] However, the great disadvantage is that we must tediously check for Lorentz invariance at each step of the calculation." (Kaku (1999) 69)

Die BRST-Quantisierung (auch als "neue kovariante Quantisierung" bezeichnet), eine Erweiterung des Fadeev-Popov-Verfahrens der Quantenfeldtheorien, stellt einen Kompromiss zwischen den vorangehend genannten Prozeduren dar. Sie verfügt über eine manifeste Unitarität wie über eine manifeste Lorentz-Invarianz, ist aber dafür komplizierter als die beiden Alternativen.

Man hat also die Wahl zwischen Ansätzen, welche die erforderlichen konzeptionellen Randbedingungen und Symmetrien deutlicher machen, und solchen, die einfacher handhabbar sind.

Innerhalb der Green-Schwarz-Formulierung des Superstringansatzes stellt die Lichtkegel-Quantisierung dann die einzige Möglichkeit dar; vgl. Kaku (1999), Kap. 3.7. und 3.8. 
Massen im Bereich von ganzzahligen Vielfachen der Planck-Masse. ${ }^{46}$ Alle diese Zustände sind als dynamische Erscheinungsformen des String anzusehen:

"The basic idea is that the string has different states with the properties of different particles. Its internal vibrations are quantized, and depending on which oscillators are excited it can look like a scalar, a gauge boson, a graviton, or a fermion." (Polchinski (1999) 10)

Wenn die Stringdynamik alle Wechselwirkungen erfassen soll, müssten alle unsere bekannten Wechselwirkungsquanten den in erster Näherung masselosen Oszillationszuständen des String entsprechen. Es müssten innerhalb des Spektrums masseloser Stringzustände gerade solche mit den entsprechenden Eigenschaften (Quantenzahlen) der bekannten Wechselwirkungsquanten existieren. Dies scheint grundsätzlich gewährleistet zu sein. Für den offenen String ergeben sich nach der Quantisierung als masselose Zustände gerade Spin-1-Vektor-Bosonen, die formal denen der starken und der elektroschwachen Wechselwirkung entsprechen. Die Eichinvarianzen der Quantenfeldtheorien und die zugehörigen Yang-MillsEichfelder ergeben sich von selbst aus der Dynamik quantisierter offener Strings:

"[...] gauge covariance is not imposed from outside, but is an intrinsic property of the string." (O'Raifeartaigh / Straumann (2000) 16)

Die spezifischen Eichinvarianzen des Standardmodells (SU(3) x SU(2) x U(1)) bleiben allerdings in ihrem möglichen Zustandekommen erst einmal unklar. ${ }^{47}$ Es gibt sehr sehr viele Alternativen für die gebrochenen Symmetrien, die aus der Stringdynamik resultieren könnten, nicht nur die des Standardmodells.

Interessanterweise führt die Quantisierung des geschlossenen String nicht zuletzt zur Vorhersage eines masselosen Spin-2-Teilchens, welches einem metrischen Feld entspricht. Dieses Spin-2-Tensor-Boson lässt sich infolge seines niederenergetischen Verhaltens mit dem Graviton identifizieren, dem postulierten Wechselwirkungsquant der Gravitation. Die simple

46 Dies gilt unter der Voraussetzung, dass sich die Stringdynamik auf der PlanckEbene abspielt. Siehe Kap. 4.1.

$47 \quad$ Siehe Dienes (1996). 
Quantisierung eines klassisch-relativistischen geschlossenen String führt also schon zur Einbeziehung der Gravitation. Die Allgemeine Relativitätstheorie lässt sich als Niederenergienäherung der Dynamik des String reproduzieren. Nur für sehr kleine Abstände treten Abweichungen von ihr auf - vielleicht genau die erhofften Korrekturen, die man für eine vereinheitlichte Theorie gegenüber ihrem geometrodynamischen Vorläufer erwarten sollte. Geschlossene Strings könnten also vielleicht als so etwas wie Anregungszustände einer Quanten-Raumzeit gesehen werden.

"[...] the effective action typically contains [...] general relativity and non-abelian gauge theory, plus stringy corrections thereof." (Lerche (2000) 16f)

Die Reproduktion des Gravitons und der Vektor-Bosonen der Eichtheorien ist das, was den Stringansatz überhaupt erst hinsichtlich der Vereinigung aller Wechselwirkungen einschliesslich der Gravitation ins Spiel gebracht hat.

\section{Supersymmetrie}

Die alte bosonische Stringtheorie ${ }^{48}$, auf die sich die vorausgehende Darstellung vor allem bezog, hat allerdings den Nachteil, dass sich im Spektrum ihrer masselosen Zustände zwar die Vektor-Bosonen der Quantenfeldtheorien und das Tensor-Boson der Gravitation finden, nicht jedoch die fermionischen Materiebestandteile. Eine Theorie, die alle Wechselwirkungen als Resultat der Stringdynamik erfasst, aber von separat existierenden fermionischen Materiebestandteilen - vielleicht sogar im Sinne von Punktentitäten - ausgehen wollte, wäre infolge dieser Inkohärenz hinsichtlich ihrer grundlegenden Ontologie wenig überzeugend. Und es wäre auch nicht klar, wie eine Wechselwirkung zwischen diesen Komponenten auszusehen hätte. Schon die Quantenfeldtheorien und die ihnen zugrundeliegenden Eichprinzipien legen eine symmetrische Beschreibung zwischen Wechselwirkungsfeldern und Materiefeldern nahe. Wenn also die Stringdynamik schon die Eichfelder der Quantenfeldtheorien reproduziert, so wäre es nur konsequent zu versuchen, auch die fermionischen Materie-

$48 \quad$ Siehe auch Kap. 4.1. 
bestandteile als Zustände des String zu erfassen. Die bosonische Stringtheorie ist dazu jedoch nicht in der Lage. In ihrem Kontext lassen sich keine fermionischen Zustände reproduzieren. Sie ist ebensowenig mit Chiralität vereinbar. ${ }^{49}$ Zudem sagt die bosonische Theorie Spin-0-Teilchen mit negativem Massequadrat voraus, Tachyonen also, die zur Instabilität des Vakuums und der Raumzeit führen würden.

Die Lösung sowohl des Tachyonen- als auch des Fermionen- und Chiralitätsproblems besteht in der Einbeziehung einer neuen Invarianz in den Stringansatz: der Supersymmetrie. ${ }^{50}$ Die Supersymmetrie ist eine Symmetrierelation hinsichtlich der Vertauschung von Bosonen und Fermionen. Sie hebt gerade den konzeptionellen Unterschied zwischen fermionischen Materiefeldern und bosonischen Wechselwirkungs-Eichfeldern auf. Eine Stringtheorie, die Fermionen einbezieht, muss, wie in einem aufwendigen historischen Prozess nach und nach entdeckt wurde, ${ }^{51}$ notwendigerweise hinsichtlich ihrer Lagrange-Funktion supersymmetrisch sein. Mittels einer solchen Theorie der "Superstrings", also der supersymmetrischen Strings, lässt sich eine Dynamik beschreiben, die bosonische und fermionische Stringzustände gleichermassen einschliesst, also auch fermionische Materieteilchen als Zustände des String zulässt.

Um die Supersymmetrie und mithin fermionische Zustände einzubeziehen, ist es erforderlich, für jeden Punkt des Weltblattes der Stringentwicklung einen Spinor zu definieren. $\mathrm{Zu}$ den d bosonischen Koordinaten-Funktionen $\mathrm{X}^{\mu}(\sigma, \tau)$, die der Lokalisierung des Weltblatts im Hintergrundraum dienen, kommen entsprechend d fermionische Majorana-Weyl-Spinoren $\Psi^{\mu}(\sigma, \tau)$ hinzu. Die Wirkungsfunktion ist dann so zu formulieren, dass sie unter Supersymmetrie-Transformationen auf dem Weltblatt des String invariant bleibt. Dann ist zu quantisieren. Im Gegensatz zur bosonischen Theorie treten dabei aufgrund der Supersymmetrie keine Tachyonen mehr auf, dafür aber neben den bekannten bosonischen die gewünschten fermionischen

49 Die Chiralität (Händigkeit) entspricht der Eigenschaft, dass sich rechts- und linkshändige (Orientierung des Spins zur Bewegungsrichtung) Fermionen hinsichtlich der schwachen Wechselwirkung unterschiedlich verhalten, was nicht zuletzt zur Verletzung der Parität führt.

50 Die Supersymmetrie verdankt ihre Entdeckung unter anderem den Entwicklungen im Bereich des Superstringansatzes. Siehe Kap. 4.1. Für die Argumente, die für die Supersymmetrie sprechen, siehe Kap. 4.2.

$51 \quad$ Siehe hierzu Kap. 4.1. 
Zustände. ${ }^{52}$ Materieteilchen und Wechselwirkungsquanten ergeben sich gleichermassen als in erster Näherung masselose Zustände des String.

\section{Wechselwirkungen}

Die von den Quantenfeldtheorien beschriebenen Wechselwirkungen stellen sich im Rahmen des Stringansatzes als die dynamische Auswirkung spezifischer Stringzustände dar. Auf der Stringebene selbst gibt es dann keine Wechselwirkung im Sinne der Quantenfeldtheorien mehr, also keine eichtheoretische Ankopplung von Wechselwirkungsfeldern an Materiefelder. Es gibt dort keinen Austausch von Wechselwirkungsquanten. Zwischen welchen Entitäten sollten diese auch ausgetauscht werden. Wechselwirkungsquanten wie Materieteilchen sind jeweils Strings in bestimmten Zuständen. Die einzig möglichen Wechselwirkungen auf der Stringebene betreffen die Strings selbst. Genauer gesagt: sie betreffen die Geometrie bzw. die Topologie der Strings. Die einzig möglichen Wechselwirkungen bestehen aus der Aufspaltung und der Fusion von Strings:

$52 \quad$ Für geschlossene Superstrings im Neveu-Schwarz-Ramond-Formalismus etwa sind - im Kontrast zur einfacheren bosonischen Theorie - die möglichen Randbedingungen für die fermionischen Felder zu beachten. Unter "Neveu-Schwarz-Randbedingungen" sind die fermionischen Felder auf dem Weltblatt antiperiodisch: $\Psi^{\mu}(\sigma+2 \pi, \tau)$ $=-\Psi^{\mu}(\sigma, \tau)$. Unter "Ramond-Randbedingungen" sind sie periodisch: $\Psi^{\mu}(\sigma+2 \pi, \tau)=$ $\Psi^{\mu}(\sigma, \tau)$. Dies führt zu vier verschiedenen Möglichkeiten für die Kombination von Neveu-Schwarz-Randbedingungen und Ramond-Randbedingungen für die linksdrehenden (antiholomorphen) und die rechtsdrehenden (holomorphen) Anteile des Schwingungszustandes des String. Nach der Quantisierung ergeben sich entsprechend vier verschiedene Hilbert-Räume für Stringzustände: Neveu-Schwarz-Neveu-Schwarz(NS-NS)-Zustände sind bosonische Stringzustände, deren links- (antiholomorphe) und rechtsdrehende (holomorphe) Anteile bosonisch sind. Beispiele hierfür sind etwa das skalare Dilaton (s.u.) und das Graviton als Tensorzustand. Ramond-Ramond-(R-R)Zustände sind bosonische Stringzustände, deren links- (antiholomorphe) und rechtsdrehende (holomorphe) Anteile fermionisch sind. Neveu-Schwarz-Ramond-(NS-R)Zustände und Ramond-Neveu-Schwarz-(R-NS)-Zustände sind fermionische Zustände. (Vgl. Polchinski (2000a), Kap. 10. sowie Kaku (1999), Kap. 3.) Für geschlossene Strings gibt es auch mit Supersymmetrie erst einmal keine Yang-Mills-Bosonen. (Anders sieht dies für die heterotischen Theorien aus, die gerade dadurch interessant werden. Siehe weiter unten.) 
"The basic string interaction is [...] one string splitting in two or the reverse. This one interaction, depending on the states of the strings involved, can look like any of the interactions in nature: gauge, gravitational, Yukawa." (Polchinski (1999) 10)

Konsequenterweise haben die Stringtheorien keine Kopplungskonstante im Sinne der Quantenfeldtheorien mehr. Die effektive Wechselwirkungsstärke ist vielmehr abhängig vom Erwartungswert des Dilaton-Felds $\phi: \mathrm{g}_{\mathrm{S}}=$ $\mathrm{e}^{\langle\phi\rangle}$. Das Dilaton, dem ein masseloses Spin-0-Skalarfeld entspricht, ist der basalste Schwingungszustand des String. ${ }^{53}$ Damit ergibt sich die effektive Wechselwirkungsstärke aus der Dynamik des String selbst. ${ }^{54}$ Sie ist das Resultat der zugrundeliegenden Dynamik und Geometrie:

"We see here that a coupling constant is given by an apriori undetermined vacuum expectation value of some field, and this reflects a general principle of string theory." (Lerche (2000) 16)

\section{Festlegung der Raumzeitdimensionen}

Eines der überraschendsten Ergebnisse des Stringansatzes besteht darin, dass die Stringtheorien nicht mit jeder beliebigen Dimension der Raumzeit vereinbar sind. Konsistenzforderungen, die vor allem dazu dienen, mathematische Anomalien ${ }^{55}$ sowie Widersprüche der Theorie mit der Quanten-

53 Das Dilaton-Feld tritt schon in der Kaluza-Klein-Theorie auf. Im allgemeinen sagt der Stringansatz weitere masselose Skalarfelder voraus, etwa die Moduli-Felder als Auswirkungen der Raumzeitgeometrie und -topologie, zu denen es im Rahmen der Kompaktifizierung kommt. Siehe Kap. 2.2. und Kap. 5. In manchen Stringansätzen kommt noch ein Axion-Skalar hinzu: ein spezielles Goldstone-Boson.

54 Der Wert der effektiven Kopplungsstärke der Strings muss nicht unbedingt klein sein, so dass es fraglich ist, ob perturbative Ansätze, die genau dies voraussetzen, überhaupt zu realistischen Lösungen führen. Vgl. Kap. 2.3.

55 Anomalien liegen dann vor, wenn klassische Symmetrien bei der Quantisierung bzw. in der quantenmechanischen Darstellung gebrochen werden. Betrifft dies Symmetrien, deren Gültigkeit auch für den quantenmechanischen Fall zu fordern ist, so werden diese Anomalien zu einem Problem. Im Stringansatz gehören zu den unbedingt zu vermeidenden Anomalien vor allem die quantenmechanische Verletzung der Eich- 
mechanik und der Speziellen Relativitätstheorie zu vermeiden, führen zu einer eindeutigen Festlegung der Dimensionszahl der Raumzeit.

"The elimination of the conformal anomaly fixes the dimension of space-time and also the fermion content of the theory, while the elimination of chiral anomalies will fix the gauge group of the theory." (Kaku (1999) 342)

Die Superstringtheorien lassen sich überhaupt nur für eine zehndimensionale Raumzeit (neun Raumdimensionen und eine Zeitdimension) konsistent formulieren:

"Consistent weakly-coupled string theories necessarily live in ten spacetime dimensions. The origin of this condition is difficult to explain in simple terms, but it can be understood in various ways. Calculation of quantum effects shows that they spoil essential symmetries unless the dimension is ten. Also, the properties of fermions depend in an essential way on the number of dimensions and ten is special here for a number of reasons related to supersymmetry." (Polchinski (1996) 18)

Dabei sind die wichtigsten der zu berücksichtigenden Konsistenzforderungen (i) die Vermeidung von Zuständen mit negativer Energie, (ii) die Berücksichtigung der Unitarität, also der Erhaltung und Normierung der quantenmechanischen Wahrscheinlichkeiten sowie (iii) die Berücksichtigung der Lorentz-Invarianz, welche gerade die Vereinbarkeit mit der Speziellen Relativitätstheorie gewährleistet.

Schon die bosonische Stringtheorie war nur auf 26 Dimensionen konsistent formulierbar. Für mehr als 26 Dimensionen ergaben sich Zustände negativer Norm, für weniger als 26 Dimensionen weitere verheerende mathematische Inkonsistenzen. Und nur für 26 Dimensionen gehörte das Graviton zu den Zuständen des geschlossenen Strings. Zur systematischen Erforschung des Möglichkeitsraums der Formulierungen des Stringansatzes wurden schon im bosonischen Modell die grundlegenden Konsistenzforderungen, vor allem Anomaliefreiheit, Unitarität und Lorentz-Invarianz, for-

invarianzen und der Diffeomorphismus-Invarianz. Die Festlegung der Raumzeitdimensionen der Stringtheorien ergibt sich insbesondere aus der Forderung des Ausschlusses von Anomalien hinsichtlich der konformen Invarianz. 
mal im Rahmen der Virasoro-Algebra ${ }^{56}$ erfasst. Die Virasoro-Algebra ist eine unendlich-dimensionale Lie-Algebra der Fourier-Moden des EnergieImpuls-Tensors. In sie fliesst insbesondere die konforme Invarianz bezüglich der Weltblattkoordinaten des String ein.

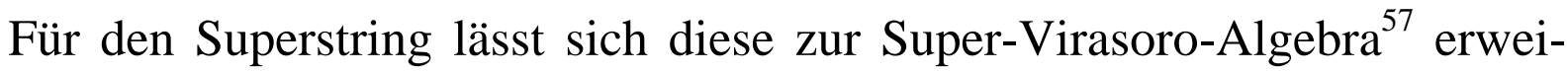
tern. Und die Super-Virasoro-Algebra der Fourierentwicklung des perturbativen Ansatzes führt nur für 10 Dimensionen nicht zu Anomalien. Für alle Dimensionen ausser 10 treten negative quantenmechanische Wahrscheinlichkeiten auf, ein deutliches Zeichen für Inkonsistenz. Für alle Dimensionen ausser 10 ist das Zustandsspektrum des String zudem nicht Lorentz-invariant, und damit nicht mit der Speziellen Relativitätstheorie vereinbar. Und vor allem, wiederum: Nur für 10 Dimensionen gehört das Graviton zu den Zuständen des String.

"In the case of fermionic strings the critical value is $d=10$. Only in this case a graviton is found in the spectrum." (Alvarez-Gaumé / Vázquez-Mozo (1992) 102)

Also ist die Theorie nur für diese Dimensionszahl überhaupt interessant, auch wenn sich konsistente Formulierungen für andere Dimensionalitäten konstruieren liessen. Genau diese Eigenschaft ist es, die sich über die konforme Invarianz in die Super-Virasoro-Algebra einschreibt. ${ }^{58}$

"That the lagrangian of general relativity, with all its complexity, just pops out from the air (arising from eg., a non interacting two dimensional field theory), may sound like a miracle. Of course this does not happen by accident, but is bound to come out. The important point here is that there is a special property that the relevant two dimensional theories must have for consistency, and this is conformal invariance. This is a quite powerful symmetry principle, which guarantees, via Ward identities, general coordinate and gauge invariance in space

\footnotetext{
$56 \quad$ Siehe Virasoro (1970).

57 Diese ergibt sich notwendigerweise im Rahmen des Neveu-Schwarz-RamondFormalismus des Superstringansatzes.

58 Im Standardmodell der Teilchenphysik führen ähnliche Überlegungen dazu, dass, um Anomalien auszuschliessen, etwa die Zahl der Leptonentypen mit der Zahl der Quarktypen übereinstimmen muss. Aber die Zahl der Raumzeitdimensionen wird hier nicht berührt.
} 
time - however, only so if and only if formally $D=10 . "$ (Lerche (2000) 17)

Die Stringtheorien sind wohl die ersten physikalischen Theorien, bei denen infolge innertheoretischer Konsistenzforderungen die Zahl der Raumzeitdimensionen festgelegt wird. ${ }^{59}$ Diese Reduzierung von Kontingenz mag zwar Probleme mit sich bringen, ${ }^{60}$ stellt aber für eine Theorie mit dem Anspruch, fundamental und umfassend zu sein, erst einmal einen erheblichen Überzeugungszugewinn dar.

\section{Fünf perturbative Superstringtheorien}

Aber die mit dem Stringansatz einhergehende Reduzierung von Kontingenz geht noch weiter: Es gibt über die Zahl der Raumzeitdimensionen hinaus weitere Festlegungen, die das Spektrum der konsistent formulierbaren Möglichkeiten einschränken. Für den perturbativen Superstring kommen aufgrund innertheoretischer Konsistenz nur wenige Theorieansätze in Frage. Die internen Festlegungen haben sich als so einschränkend erwiesen, dass es sehr schwierig ist, überhaupt eine konsistente Theorie zu formulieren. Die Ursache dafür liegt, wie zuvor schon angedeutet, darin begründet, dass sich zwar für Punktentitäten mit ihren eindimensionalen Weltlinien beliebige Wechselwirkungen formulieren lassen, die Weltblätter der Stringdynamik als Riemannsche Mannigfaltigkeiten hingegen schon vielfältige geometrische und topologische Festlegungen für die möglichen Wechselwirkungen von Strings liefern:

"This world sheet, in turn, is a genuine manifold, a Riemann surface, so the set of interactions consistent with the propagator is severely li-

$59 \quad$ Es gibt inzwischen noch einen weiteren Ansatz, für den dies gilt, nämlich das Modell des computationalen Universums von Seth Lloyd, in dem sich die Quantengravitation und die Raumzeit auf der Basis elementarer Quantencomputationen konstituieren:

"Because quantum logic gates have two inputs and two outputs, four dimensions arise naturally in the computational universe. [...] In the computational universe, the four dimensional structure of spacetime arises out of pairwise interactions between information-bearing degrees of freedom." (Lloyd (2005) 25)

Siehe Kap. 2.2. 
mited. Thus, we expect to find a very small number of string theories, in contrast to the infinite number of point particle theories we can write." (Kaku (1999) 51)

Es scheint genau fünf perturbative Superstringtheorien zu geben, die frei von Anomalien sind. Diese werden als Typ I, Typ IIA, Typ IIB, Heterotisch-SO(32) sowie Heterotisch- $\mathrm{E}_{8} \mathrm{xE}_{8}$ bezeichnet:

"The Type IIA and Type IIB strings differ in that in the latter theory [the] clockwise / counterclockwise vibrations are identical, while in the former, they are exactly opposite in form. Opposite has a precise mathematical meaning in this context, but it's easiest to think about in terms of the spin of the resulting vibrational patterns in each theory. In the Type IIB theory, it turns out that all particles spin in the same direction (they have the same chirality), whereas in the Type IIA theory, they spin in both directions (they have both chiralities). [...] The heterotic theories differ in a similar but more dramatic way. Each of their clockwise string vibrations looks like those of the Type II string (when focusing on just the clockwise vibrations, the Type IIA and Type IIB theories are the same), but their counterclockwise vibrations are those of the original bosonic string theory. Although the bosonic string has insurmountable problems when chosen for both clockwise and counterclockwise string vibrations, in 1985 David Gross, Jeffrey Harvey, Emil Martinec, and Ryan Rhom (all then at Princeton University and dubbed the 'Princeton String Quartet') showed that a perfectly sensible theory emerges if it is used in combination with the Type II string. The really odd feature of this union is that it has been known [...] that the bosonic string requires a 26dimensional spacetime, whereas the superstring [...] requires a 10dimensional one. So the heterotic string constructions are a strange hybrid - a heterosis - in which counterclockwise vibrational patterns live in 26 dimensions and clockwise patterns live in 10 dimensions! Before you get caught up in trying to make sense of this perplexing union, Gross and his collaborators showed that the extra 16 dimensions on the bosonic side must be curled up into one of two very special higher-dimensional doughnutlike shapes, giving rise to the $\mathrm{He}$ terotic-O and Heterotic-E theories. Since the extra 16 dimensions on the bosonic side are rigidly curled up, each of these theories behaves as though it really has 10 dimensions, just as in the Type II case. 
Again, both heterotic theories incorporate a version of supersymmetry. Finally, the Type I theory is a close cousin of the Type IIB string except that, in addition to the closed loops of string [...] it also has strings with unconnected ends - so called open strings." (Greene (1999) 405f)

Die Theorie vom Typ I ist die alte supersymmetrische Stringtheorie der siebziger und frühen achtziger Jahre. ${ }^{61}$ Diese Theorie beschrieb erst einmal nur geschlossene, unorientierte Strings mit chiralen Eigenschaften. Für die links- (antiholomorphen) und die rechtsdrehenden (holomorphen) Schwingungszustände gelten gleiche Supersymmetrietransformationseigenschaften. ${ }^{62}$ Es zeigte sich jedoch, dass die Theorie vom Typ I aus Konsistenzgründen um offene, unorientierte Strings erweitert werden muss. An den Enden des offenen Strings werden dabei, wiederum um Anomalien zu verhindern, Eichladungen als Chan-Paton-Faktoren angefügt. Das Resultat entspricht der Einführung einer Yang-Mills-Eichgruppe SO(32).

"It turns out that the mathematically consistent theories of open strings also require that a charge label be associated with each end of the string." (Giddings (2005) 7)

Die Theorie vom Typ IIA ${ }^{63}$ enthält ausschliesslich geschlossene, orientierte Strings mit unterschiedlichen Supersymmetrietransformationseigenschaften und gegensätzlicher Chiralität für die links- (antiholomorphen) und die rechtsdrehenden (holomorphen) Schwingungszustände. ${ }^{64}$ Die Theorie vom Typ IIB ${ }^{65}$ enthält ebenfalls ausschliesslich geschlossene, orientierte Strings mit unterschiedlichen Supersymmetrietransformationseigenschaften, aber gleicher Chiralität für die links- (antiholomorphen) und die rechtsdrehenden (holomorphen) Schwingungszustände. ${ }^{66}$

61 Siehe Ramond (1971) und Neveu / Schwarz (1971). Heute lässt sich diese Theorie als Projektion der Typ-IIB-Theorie ansehen.

62 Die Supersymmetrie ist vom Typus $N=1$. N ist die Zahl der Generatoren innerhalb der Supersymmetrie. Siehe etwa Zumino (1979).

63 Siehe Green / Schwarz / Brink (1983).

64 Die Supersymmetrie ist vom Typus N=2. Die Eichgruppe der Stringzustände ist $\mathrm{U}(1)$.

65 Siehe Green / Schwarz / Brink (1983).

66 Die Supersymmetrie ist wiederum vom Typus N=2. Es gibt keine Eichgruppe. 
Da als Zustände geschlossener Strings im Rahmen der gängigen perturbativen Konzeptionen erst einmal keine Spin-1-Yang-Mills-Eichbosonen in Frage kommen, lassen diese sich in den Theorien vom Typus IIA und IIB nicht ohne weiteres unterbringen. ${ }^{67}$ In der Theorie vom Typus I lassen sie sich nur für offene Strings reproduzieren. Hier ist der Preis aber die Einführung problematischer Chan-Paton-Faktoren. Nicht zuletzt um eine Lösung dieses Problems zu erreichen, wurden die heterotischen Theorien entwickelt: ${ }^{68}$

"Until recently, the only known anomaly-free chiral superstring theory was that of orientable, type II, N=2 supersymmetric closed strings. This ten-dimensional theory does not contain Yang-Mills interactions; it is unlikely that they, together with the known fermions, could emerge upon compactification. The recent discovery that nonorientable, type I, open and closed superstrings with $N=1$ supersymmetry are finite and anomaly free if the gauge group is $S O(32)$ has increased the phenomenological prospects of unified string theories. / The anomaly cancellation mechanism of Green and Schwarz can be understood in terms of the low-energy field theory that emerges from the superstring, which is a slightly modified version of $D=10$ supergravity. The dangerous Lorentz and Yang-Mills chiral anomalies cancel if and only if the gauge group of the theory is $S O(32)$ or $E_{8} x E_{8}$. The ordinary superstring theory cannot incorporate $E_{8} x E_{8}$. However the apparent correspondence between the low-energy limit of anomaly-free superstring theories and anomaly-free supergravity theories suggests the existence of a new kind of string theory whose low-energy limit would contain an $E_{8} x E_{8}$ gauge group. This is the motivation that led to the construction of the heterotic string. It is of more than academic interest to construct such a theory, since the phenomenological prospects for an $E_{8} x E_{8}$ theory appear to be much brighter." (Gross / Harvey / Martinec / Rohm (1985) 254)

67 Dies relativiert sich im Rahmen der Kompaktifizierung bzw. mit den Dualitätsbeziehungen zwischen den Stringtheorien und es verliert seine Relevanz mit den Entdeckung der Dirichlet-Branen. Siehe Kap. 2.2., 2.3. bzw. 2.4.

$68 \quad$ Siehe Gross / Harvey / Martinec / Rohm (1985). 
Die heterotischen Theorien erscheinen auf den ersten Blick als ein recht kurioses Mischkonstrukt, das sich allerdings bei genauerer Betrachtung als vielversprechend herausstellt.

"The word 'heterosis' implies 'hybrid vigor'." (Kaku (1999) 374)

Denn obwohl die heterotischen Theorien nur geschlossene Strings enthalten, lassen sich mit ihnen Zustände beschreiben, die Yang-Mills-Bosonen entsprechen. Dies erreichen sie dadurch, dass sie Eigenschaften der bosonischen Stringtheorien mit denen der Superstringtheorien mischen.

"[...] the theory [...] is a fusion (heterosis) of the bosonic and type II strings." (Polchinski (2000a) 51)

Für geschlossene Strings sind die rechtsorientierten (holomorphen) und die linksorientierten (antiholomorphen) Schwingungen grundsätzlich voneinander unabhängig. Die beiden Algebren kommutieren hinsichtlich ihrer jeweiligen Operatoren. ${ }^{69}$ Die heterotische Konzeption besteht nun gerade darin, für die linksorientierten (antiholomorphen) Schwingungen einen bosonischen String in 26 Dimensionen anzusetzen ${ }^{70}$ und für die rechtsorientierten (holomorphen) Schwingungen einen Superstring in 10 Dimensionen. $^{71}$ Die gegenüber dem Superstring zusätzlichen 16 bosonischen Dimensionen müssen dabei nicht notwendigerweise raumzeitlich interpretiert werden, ${ }^{72}$ sondern können ebenso als formal geometrisiertes Muster zur

69 Dies gilt nicht für offene Strings, so dass heterotische Konstruktionen für diese nicht möglich sind.

Rolle mehr:

"The left-moving side, like the bosonic string, has a would-be tachyon, but there

is no right-mover to pair it with so the theory is tachyon free." (Polchinski (2000a) 52)

71 Die Supersymmetrietransformationseigenschaften vom Typus N=1 gelten nur für die rechtsdrehenden (holomorphen) Schwingungszustände.

72 Ihr Status als interne Dimensionen lässt sich insofern stützten, als die Formulierung der heterotischen Theorie, im Rahmen einer Fermionisierung der inneren Koordinaten, auch ohne sie auskommt:

"An alternate version of the heterotic string can be given in which these coordinates are replaced by 32 fermionic coordinates." (Gross / Harvey / Martinec / Rohm (1985) 256) 
Parametrisierung zusätzlicher interner, nur quasi-raumzeitlicher Freiheitsgrade angesehen werden: ${ }^{73}$

"The last 16 bosonic coordinates can be interpreted as parametrizing an internal manifold. Consistency of the resulting theory impose that this internal manifold has to be a 16-dimensional torus [...]." (Alvarez-Gaumé / Vázquez-Mozo (1992) 112) ${ }^{74}$

In der zehndimensionalen Raumzeit treten die (quasi-)raumzeitlichen Symmetrien der 16 zusätzlichen bosonischen Dimensionen als Skalarfelder in Erscheinung. ${ }^{75}$ Das Vektor-Bosonen-Multiplett hingegen, das sich ebenfalls als Ergebnis des formalen 26-zu-10-Übergangs einstellt, repräsentiert die eigentlichen inneren Symmetrien der bosonischen Dimensionen. Aus dem dimensionalen Übergang resultiert gerade die Symmetriegruppe der Theorie. Es gibt zwei Varianten der heterotischen Theorie: eine mit der Eichgruppe $\mathrm{SO}(32)$ und eine andere mit der Eichgruppe $\mathrm{E}_{8} \times \mathrm{E}_{8}$ :

"The heterotic string theory is a theory of closed strings, in which the compactification of sixteen internal dimensions produces the gauge group $S O(32)$ or $E_{8} x E_{8} . "$ (Gross / Harvey / Martinec / Rohm (1985)

73 Man kann für den heterotischen String im Sinne der in Kap. 2.2. zu erörternden Kompaktifizierungsmodi gleichermassen von einer Kompaktifizierung in zwei Stufen ausgehen: 26 -> 10 -> 4. Die physikalische Bedeutung einer solchen Vorgehensweise ist jedoch alles andere als klar:

"We could try to go further and combine the whole left-moving side of the bosonic string, with 26 flat dimensions, with the ten-dimensional right-moving side of the type II string. In fact this can be done, but since its physical meaning is not so clear we will for now keep the same number of dimensions on both sides." (Polchinski (2000a) 49)

74 "For consistent compactification of supersymmetric coordinates there is a strong evidence that it suffices for $T$ to be Ricci flat. The only known consistent possibility for compactification of purely bosonic coordinates is for T to be a flat torus." (Gross / Harvey / Martinec / Rohm (1985) 260)

75 Auch eine geometrische Kompaktifizierung im Sinne von Kap. 2.2. hat gerade diese Skalarfelder zur Folge:

"The compactification of a dimension creates a quantization of the momentum corresponding to the compactified coordinate." (Kaku (1999) 375) 
Das heterotische Konzept entspricht damit einerseits einer neuen Methode zur Implementierung von Ladung, die das Chan-Paton-Verfahren obsolet macht: ${ }^{76}$

"Heterotic strings are closed, so that there is no place to attach charges as one does in the case of open strings. Instead the gauge group arises via a Kaluza-Klein-type mechanism stemming from the compactification of 16 of the internal coordinates of the string." (Gross / Harvey / Martinec / Rohm (1985) 282)

Bis zur Entwicklung der heterotischen Theorien ging man andererseits davon aus, dass man geschlossene Strings für die Darstellung von masselosen Spin-2-Tensor-Zuständen (Gravitonen) und offene Strings für die von masselosen Spin-1-Vektor-Zuständen (Yang-Mills-Bosonen) benötigt. Der Vorteil der heterotischen Theorien liegt nun darin begründet, dass sich alle diese Zustände für einen geschlossenen heterotischen String ergeben. Konsequenterweise wurde das heterotische Konzept lange Zeit als idealer Ansatz zur Reproduktion sowohl des quantenfeldtheoretischen Standardmodells und seiner Eichsymmetrien als auch der allgemein-relativistischen Gravitationsdynamik betrachtet:

"[...] the Standard Model $S U(3) \times S U(2) \times U(1)$ gauge symmetries must come from the left-moving gauge symmetries in heterotic string theory." (Polchinski (2000a) 340)

Insbesondere die heterotische Theorie mit der Eichgruppe $\mathrm{E}_{8} \times \mathrm{E}_{8}$ wurde als Lösung hierfür ins Auge gefasst. Aus ihr sollten sich die Eichinvarianzen und die Yang-Mills-Eichfelder des Standardmodells ableiten lassen. Inzwischen hat sich diese Einschätzung aus Gründen, die noch zu erörtern sein werden, relativiert. ${ }^{77}$ Vor allem ist klar geworden, dass sich sehr viele spezifische Eichinvarianzen ableiten lassen, bei weitem nicht nur die des Standardmodells.

76 Eine weitere Alternative hierzu entsteht dann schliesslich mit der Entdeckung der Möglichkeit, Dirichlet-Brane in die Stringtheorie einzubeziehen. Siehe Kap. 2.4.

77 Siehe hierzu vor allem Kap. 5. Andererseits weiss man inzwischen auch, dass sich Gravitonen sogar in Theorien mit offenen Strings integrieren lassen: als intermediäre Wechselwirkungszustände dieser offenen Strings. 
Aber grundsätzlich stellt sich immer noch die Frage, wieso es überhaupt fünf konsistente perturbative Theorien gibt - und nicht nur eine. Schliesslich ist der Anspruch des Superstringansatzes der, eine fundamentale Theorie zu liefern, die alle Wechselwirkungen vereinigt. Und die Reduzierung der Kontingenz durch Einengung der konsistenten Möglichkeiten war durchgängig eines der stärksten Argumente für diesen Anspruch. Wenn dieses Argument ernst genommen werden kann, warum sollten dann am Ende fünf Möglichkeiten und nicht nur eine übrig bleiben?

"It's puzzling that there should be five perfectly finite, self-consistent field theories which combine gravity with other quantum forces." (Kaku (1999) 460)

Eine Lösung für dieses Problem einer immer noch zu grossen Vielfalt an Möglichkeiten liefern nach Ansicht vieler Stringtheoretiker die noch zu erörternden Dualitäten, mit deren Hilfe sich Beziehungen zwischen den fünf bekannten perturbativen Superstringtheorien herstellen lassen. ${ }^{78}$ Andererseits ist es aber nicht einmal klar, ob es nicht vielleicht noch weitere perturbative Stringtheorien gibt:

"It should be emphasized that the analysis [...] had many explicit and implicit assumptions, and one should be cautious in assuming that all string theories have been found." (Polchinski (2000a) 48)

$78 \quad$ Siehe Kap. 2.3. 


\subsection{Kompaktifizierung und Calabi-Yau-Räume}

Die perturbative Dynamik supersymmetrischer Strings ist mathematisch konsistent nur auf zehn raumzeitlichen Dimensionen formulierbar. Unsere phänomenologische Raumzeit verfügt aber nur über vier Dimensionen: drei räumliche und eine zeitliche. Wie lässt sich mit dieser Diskrepanz umgehen? Zeigt sich in dieser Tatsache, dass die Stringtheorien falsch sind eine Sackgasse der physikalischen Theorienbildung? Oder zeigt sich vielmehr, dass wir nur einen Teil der tatsächlich vorhandenen raumzeitlichen Dimensionen wahrnehmen? - Die Stringtheoretiker gehen von letzterem aus. Es werden verschiedene Szenarien geltend gemacht, warum wir von den zehn raumzeitlichen Dimensionen nur vier wahrnehmen. Diese unterschiedlichen Szenarien könnten, wie sich vielleicht einmal herausstellen mag, wenn der Stringansatz sich erfolgreich ausformulieren lassen sollte, unterschiedliche Darstellungen ein und desselben Sachverhaltes sein. Sie könnten sich aber andererseits auch als distinkte physikalische Möglichkeiten herausstellen.

Das gängigste dieser Szenarien ${ }^{79}$ des Übergangs von zehn zu vier raumzeitlichen Dimensionen ist das der Kompaktifizierung der überzähligen Dimensionen. ${ }^{80}$ Diese sollen auf mikroskopischer Ebene eingerollt sein. Die zehndimensionale Raumzeit der (perturbativen) Superstringtheorien stellt sich in diesem Szenario als Produkt aus einer vierdimensionalen Minkowski-Raumzeit und einer kompakten sechsdimensionalen Mannigfaltigkeit $\mathrm{K}$ dar: $\mathrm{R}^{4}$ x K. Meist geht man von einer Kompaktifizierung in der Grössenordnung der Planck-Länge aus.

"Specifically, the simplest way to get down to four dimensions is to assume / postulate that the spacetime manifold is not simply $R^{10}$, but $R^{4}$ $x X_{6}$, where $X_{6}$ is some compact six-dimensional manifold." (Lerche (2000) 18) 
Eine kompakte räumliche Dimension gab es schon im Kaluza-KleinAnsatz zur Vereinigung von elektromagnetischer und gravitativer Wechselwirkung. Die zum Zweck der Vereinigung der Wechselwirkungen postulierte fünfte Raumzeitdimension sollte in Form eines Torus eingerollt sein. Im Stringansatz geht es aber nun um alle Wechselwirkungen. Einerseits macht dies vielleicht plausibel, wieso es jetzt um sechs kompakte Dimensionen geht. Andererseits gibt es für die eingerollten, kompaktifizierten Dimensionen dann nicht mehr nur die simple Möglichkeit sechsdimensionaler Tori. Es sind vielmehr topologisch wesentlich kompliziertere Mannigfaltigkeiten für die Kompaktifizierung der sechs überzähligen Dimensionen denkbar. ${ }^{81}$ Und die kompakte Mannigfaltigkeit kann grundsätzlich wohl auch Singularitäten enthalten. ${ }^{82}$ Bei genauerer Betrachtung stellt sich schliesslich heraus, dass die Supersymmetrieanforderung der Strings nur für bestimmte Formen der Kompaktifizierung gewährleistet ist, da die geometrischen und topologischen Formen der kompakten Raumzeitdimensionen naheliegenderweise einen wesentlichen Einfluss auf die möglichen Schwingungszustände des String haben: ${ }^{83}$

"The most intuitive of these constructions are those in which six of the ten spatial dimensions [...] are 'compactified'. That is, they are replaced by a small compact six dimensional space, say $M$ [...]. It is crucial to realize that most choices for $M$ will not yield a consistent string theory [...]. These conditions together are referred to as the 'CalabiYau' conditions and manifolds $M$ meeting them are known as CalabiYau three-folds [...]. A consistent string model, therefore, with four flat Minkowski space-time directions can be built using any CalabiYau three-fold as the internal target space [...]." (Greene (1997) 9)

Mit der raumzeitlichen Supersymmetrie ist nur eine Kompaktifizierung vereinbar, bei der sich die zehndimensionale Raumzeit der (perturbativen) Superstringtheorien als Produkt aus einer vierdimensionalen Minkowski-

81 Die komplexe Mannigfaltigkeit K sollte mit einer angemessenen HolonomieGruppe und Metrik versehen sein, was mathematisch bisher nur unzulänglich verstanden ist.

82 Siehe Kap. 2.4. Dirichlet-Brane kommen etwa als solche Singularitäten in Frage.

${ }_{83}$ Siehe Candelas / Horowitz / Strominger / Witten (1985). 
Raumzeit und einem kompakten sechsdimensionalen Calabi-Yau-Raum darstellt. $^{84}$

"The extra spatial dimensions of string theory cannot be 'crumpled' up any which way; the equations that emerge from the theory severely restrict the geometrical form that they can take. In 1984, Philip Candelas of the University of Texas at Austin, Gary Horowitz and Andrew Strominger of the University of California at Santa Barbara, and Edward Witten showed that a particular class of six-dimensional geometrical shapes can meet these conditions. They are known as CalabiYau spaces (or Calabi-Yau shapes) in honor of two mathematicians, Eugenio Calabi from the University of Pennsylvania and Shing-Tung Yau from Harvard University, whose research in a related context, but prior to string theory, plays a central role in understanding these spaces." (Greene (1999) 207)

Calabi-Yau-Räume ${ }^{85}$ sind Kähler-Mannigfaltigkeiten mit verschwindender erster Chern-Klasse. Kähler-Mannigfaltigkeiten wiederum sind komplexe Mannigfaltigkeiten mit spezieller Hermitscher Metrik. Komplexe Mannigfaltigkeiten bzw. komplexe n-Faltigkeiten lassen sich durch n komplexe Koordinaten und damit $\mathrm{d}=2 \mathrm{n}$ Dimensionen charakterisieren. Calabi-Yau$\mathrm{n}$-Faltigkeiten haben insofern $\mathrm{n}$ komplexe und somit $2 \mathrm{n}$ reale Koordinaten. Die für die Kompaktifizierung in den supersymmetrischen Stringtheorien infragekommenden sechsdimensionalen Calabi-Yau-Räume sind also CY3-Faltigkeiten. Nach Yaus Theorem existiert für CY-n-Faltigkeiten eine Ricci-flache Metrik mit SU(n)-Holonomie. Dies ist gerade die Voraussetzung für die Supersymmetrie. Die Mathematik der Calabi-Yau-Räume ist bisher jedoch nur unzureichend erschlossen.

"In practive, however, Calabi-Yau manifolds are quite difficult to construct and only a few of them are actually known." (Kaku (1999) 434)

84 Die einzige für die Kompaktifizierung der überzähligen Dimensionen der supersymmetrischen Stringtheorien infragekommende Alternative zur Calabi-YauStruktur besteht darin, den zehndimensionalen Raum als Produkt aus einer vierdimensionalen Minkowski-Raumzeit, einem zweidimensionalen kompakten Torus und einer vierdimensionalen kompakten K3-Mannigfaltigkeit darzustellen. K3 ist das einzig bekannte vierdimensionale Analogon zu Calabi-Yau-Räumen.

Siehe Hübsch (1992). 
Nach heutiger Einschätzung gibt es etwa zehntausend topologisch unterschiedliche Typen von sechsdimensionalen Calabi-Yau-Räumen, die sich noch einmal in ihren weiteren geometrischen Parametern unterscheiden können. Die Geometrie und Topologie der kompakten Mannigfaltigkeit lässt sich durch die sogenannten Moduli charakterisieren. ${ }^{86}$ Moduli sind geometrische Parameter, welche die Grösse und Form der kompakten Mannigfaltigkeit erfassen, vor allem aber ihre Topologie. Jeder Punkt im Raum der Moduli-Varianten steht für eine spezifische sechsdimensionale kompakte Mannigfaltigkeit.

Die Kompaktifizierung selbst ist infolge der postulierten Ausdehnung der kompakten Dimensionen letztlich unbeobachtbar. Sie macht sich aber dadurch bemerkbar, dass die Geometrie des kompakten Raumes die möglichen Schwingungsmuster des String auf der resultierenden Vierer-Raumzeit bestimmt: ${ }^{87}$

"At energies greater than the inverse of the small dimensions, one can excite particles moving in those directions. The states are quantized because of the finite size, and each state of motion looks, from the lower-dimensional point of view, like a different kind of particle. Thus the signature of passing such a threshold is a whole tower of new particles, with a spectrum characteristic of the shape of the extra dimension." (Polchinski (1999) 6)

So lässt sich die Kompaktifizierung als geometrische Interpretation der Parametrisierung der möglichen Zustandsspektren des String verstehen. ${ }^{88}$ Die Moduli-Varianten sind den jeweils möglichen Unterklassen der konsistenten Lösungen des perturbativen Stringansatzes zugeordnet. Auf der vierdimensionalen nicht-kompakten Minkowski-Raumzeit manifestieren sich die Moduli selbst als skalare Moduli-Felder. ${ }^{89}$ Sie treten also nicht in geo-

S6 Siehe Candelas / Ossa (1991).

87 Hier klingt Einsteins und Wheelers Geometrisierungsprogramm zumindest wieder an, auch wenn der Kontext nun ein völlig anderer ist.

88 Man muss die kompakten Dimensionen also nicht notwendigerweise als tatsächlich raumzeitlich deuten.

89 Die Moduli treten in der vierdimensionalen Raumzeit als gravitativ gekoppelte Skalarfelder in Erscheinung. Solche Skalarfelder wurden bisher nicht nur noch nicht beobachtet, sondern sie sind in gewisser Hinsicht unphysikalisch, denn sie führen zu langreichweitigen Wechselwirkungen, die mit der Gravitation konkurrieren und das 
metrischer Form in Erscheinung, wirken sich aber direkt auf die möglichen Spektren der Stringzustände aus. Nicht zuletzt das für die effektive Wechselwirkungsstärke verantwortliche Dilaton-Feld, das dem Grundzustand des String entspricht, ist ein Modulus-Feld. Die inneren Symmetrien der kompakten Mannigfaltigkeit manifestieren sich darüberhinausgehend infolge der durch sie bestimmten Schwingungsmodi des String auf der vierdimensionalen Minkowski-Raumzeit als Eichfelder einer effektiven Theorie. $^{90}$

"[...] the isometry group of the internal manifold appears as part of the gauge group of the low energy effective field theory." (AlvarezGaumé / Vázquez-Mozo (1992) 75)

Die Erhaltungsgrössen der Dynamik innerhalb des kompakten Raumes erscheinen in der nicht-kompakten Vierer-Raumzeit als Ladungen (Wechselwirkungsgrössen). Dies macht im Rahmen der Kompaktifizierung das Chan-Paton-Verfahren und die Implementierung von Ladungen durch heterotische Konstruktionen letztlich obsolet. Und im Rahmen der Kompaktifizierung lassen sich Zustände beliebigen Spins dem gleichen Stringtypus zuordnen, etwa einem geschlossenen String vom Typ IIA. Die Idee, dass man geschlossene Strings für die Darstellung von masselosen Spin-2-Tensor-Zuständen und offene Strings für die von masselosen Spin-1-VektorZuständen benötigt oder aber zu heterotischen Konstruktionen greifen muss, verliert damit ihre Relevanz.

"Physics is much the same in a spacetime with three large spatial dimensions and additional ones which are small and compact. In nature, the additional dimensions would be quite small, close to the Planck scale, so we would have seen only the very lowest modes. One reason this is attractive is that it unifies gravitational and gauge interactions. Depending on whether its polarization is aligned along the long or compact directions, a higher-dimensional graviton can look like a graviton, photon, or scalar from the lower-dimensional point of view." (Polchinski (1996) 18)

Äquivalenzprinzip verletzen. Man hofft, dass es sich nur um ein Artefakt der perturbativen Theorieansätze handelt. Siehe Candelas / Ossa (1991).

$90 \quad$ Vgl. den analogen Sachverhalt für die 16 bosonischen Dimensionen der heterotischen Theorien; Kap. 2.1. 
Infolge der vielfältigen Möglichkeiten für die Geometrie und Topologie der kompakten Mannigfaltigkeit und der spezifischen Konsequenzen jeder einzelnen diese Möglichkeiten gestaltet sich die Ableitung direkter Vorhersagen jedoch sehr schwierig.

"Now, we would be more than glad if strings would remain in lower dimensions as simple as they are in $D=10$. However, especially string theories in $D=4$ turn out to be much more complicated." (Lerche (2000) 18)

"No one really knows how to break a 10-dimensional theory down to four dimensions." (Kaku (1999) 18)

Aber immerhin lässt sich ein Zusammenhang zwischen dem Kompaktifizierungsmodus bzw. seiner Topologie und der Zahl der für die vierdimensionale Physik zu erwartenden Zahl der Teilchenfamilien herstellen: Die Zahl der Teilchengenerationen ist gleich dem halben Absolutbetrag der charakteristischen Euler-Zahl des kompakten Raumes. Und es lässt sich vor allem motivieren, wieso es überhaupt Teilchenfamilien gibt. Sie entsprechen im Stringansatz den strukturellen Implikationen für die Schwingungsspektren, welche sich aus der spezifischen geometrischen Struktur einer kompakten Mannigfaltigkeit eines bestimmten topologischen Typus ergeben.

"In the Standard Model, there are several notable patterns in the gauge quantum numbers of the quarks and leptons: replication of generations, chirality, quantization of the electric charge, and absence of large ('exotic') representations of $S U(2)$ and $S U(3)$. We have seen in the orbifold and the Calabi-Yau examples that multiple generations arise frequently in four-dimensional string theories. This is an attractive feature of higher-dimensional theories in general. The generations arise from massless excitations that differ in the compact dimensions but have the same spacetime quantum numbers." (Polchinski (2000a) 337) ${ }^{91}$

Lange Zeit hoffte man, dass sich im Rahmen der Erforschung der möglichen Kompaktifizierungsmodi supersymmetrischer Strings herausfinden

91 Zur Orbifold-Technik als Darstellungsalternative zur Calabi-Yau-Kompaktifizierung siehe Polchinski (2000a), Kap. 16. bzw. Kaku (1999), Kap. 10. 
lässt, wie es zum Standardmodell der Quantenfeldtheorien als effektiver Theorie im Niederenergiebereich kommt. Aber diese Hoffnungen haben sich inzwischen weitgehend zerschlagen. Die unterschiedlichen Möglichkeiten einer Kompaktifizierung für die überzähligen Dimensionen treten innerhalb der Vierer-Raumzeit jeweils sehr unterschiedlich in Erscheinung. Unterschiedliche Kompaktifizierungsmodi führen $\mathrm{zu}$ unterschiedlicher Physik innerhalb der Vierer-Raumzeit. Und mit der Vielfalt an Optionen für die Geometrie des kompakten Raumes kommt es innerhalb des Stringansatzes zur Unbestimmtheit und Unvorhersagbarkeit hinsichtlich der physikalischen Implikationen für die Vierer-Raumzeit:

"[...] there are many Calabi-Yau three-folds and each gives rise to different physics in $M_{4}$. Having no means to choose which one is 'right', we lose predictive power." (Greene (1997) 9)

Die Bedingungen, unter denen man etwa die Reproduktion des Standardmodells erwarten würde, hängen entscheidend vom jeweiligen Kompaktifizierungsmodus ab. Inzwischen steht aber fest, dass das Spektrum der Möglichkeiten für die Kompaktifizierung und entsprechend für das Spektrum ihrer möglichen physikalischen Implikationen immens ist. Die Zahl der möglichen String-Vakua wird heute auf $10^{100}$ bis $10^{500}$ geschätzt. $^{92}$ Für diese unüberschaubare Alternativenlandschaft hat sich inzwischen die Bezeichnung "String-Landscape" eingebürgert. Und es sieht zudem danach aus, als ob sich kein innertheoretisch motivierbares Kriterium für die Auswahl einer der Alternativen bietet. Im Rahmen der Erforschung der möglichen Kompaktifizierungsmodi haben die Stringtheoretiker offensichtlich die Büchse der Pandora geöffnet. Aber davon soll später ausführlich die Rede sein. ${ }^{93}$

92 Siehe Kap. 5. sowie Banks et al. (2003), Dine (2004), Douglas (2003) und Susskind (2003).

93 Siehe Kap. 5. 


\subsection{Dualitäten und M-Theorie}

Es gibt (mindestens) fünf konsistente perturbative Stringtheorien und nicht nur eine. Dies ist aber nur schwerlich mit dem Anspruch des Superstringansatzes zu vereinbaren, die fundamentale Theorie zu sein, die alle Wechselwirkungen vereinigt. Eine Lösung für dieses Problem findet sich vielleicht in den Dualitätsbeziehungen zwischen den bekannten fünf perturbativen Theorien. Diese weisen auf einen diesen Theorien zugrundeliegenden umfassenderen gemeinsamen konzeptionellen Rahmen hin, eine nichtperturbative Theorie, die bisher noch nicht in klar ausformulierbarer Weise existiert, aber dennoch schon einen Namen trägt: M-Theorie.

Dualitätsbeziehungen bestehen darin, dass die Zustandsspektren zweier zueinander dualer Beschreibungen unter bestimmten, eindeutig zu spezifizierenden parametrischen Bedingungen identisch sind. Dies deutet auf die unter den jeweiligen spezifischen Bedingungen gegebene Äquivalenz der zueinander dualen Beschreibungen hin. Dualitätsbeziehungen sind nach Auffassung einiger Theoretiker ein spezifisches Charakteristikum des Stringansatzes: ${ }^{94}$

"Duality is a typical 'stringy' property without any counterpart in field theory, since it depends crucially on the extended nature of the string." (Alvarez-Gaumé / Vázquez-Mozo (1992) 77)

Sie werden offensichtlich durch die Supersymmetrie begünstigt und lassen sich nach heutigem Ermessen vor allem auf die Tatsache zurückführen, dass es zu den für die herkömmlichen Quantenfeldtheorien typischen Divergenzen in supersymmetrischen Theorien infolge der gegenseitigen Auslöschung von bosonischen und fermionischen Anteilen oft erst gar nicht kommt:

"Duality symmetries are most manifest in supersymmetric theories, because in such theories perturbative loop corrections tend to be suppressed, due to cancellations between bosonic and fermionic degrees of freedom." (Lerche (2000) 20)

$94 \quad$ Siehe Hull / Townsend (1995), Polchinski (1996). 
Die für den Stringansatz relevanten Dualitäten sind bisher jedoch nur für einige Spezialfälle nachgewiesen. Ein allgemeiner Beweis steht immer noch aus, so dass sie bestenfalls den Status plausibler Hypothesen haben. Dies gilt gleichermassen für alle auf ihnen aufbauenden Schlussfolgerungen.

\section{T-Dualität}

Der einfachste Typus der im Stringansatz auftretenden Dualitätsbeziehungen ist die T-Dualität ("target-space duality"). ${ }^{95}$ Sie ergibt sich für geschlossene Strings, die sich um eine kompakte zylindrische Dimension winden, in der Form, dass das Zustandsspektrum einer Stringtheorie A bei einer zylindrischen Kompaktifizierung mit dem Radius $\mathrm{R}_{A}=\mathrm{R} \mathrm{l}_{\mathrm{S}}\left(\mathrm{l}_{\mathrm{S}}\right.$ steht für die Stringlänge) identisch ist mit dem Zustandsspektrum einer Stringtheorie $\mathrm{B}$ bei einer zylindrischen Kompaktifizierung mit dem Radius $\mathrm{R}_{\mathrm{B}}=$ ${ }_{S} / R$. Für $R_{A} R_{B}=1_{S}{ }^{2}$ kommt es zu den gleichen Zustandsspektren für die beiden T-dualen Stringtheorien A und B.

Die T-Dualität konnte bisher zwischen den beiden heterotischen Theorien $\mathrm{E}_{8} \times \mathrm{E}_{8}$ und $\mathrm{SO}(32)$ ebenso wie zwischen den Theorien vom Typ IIA und vom Typ IIB nachgewiesen werden. Im letzteren Fall bedeutet dies bei Kompaktifizierungsradiusinversion eine Äquivalenz hinsichtlich der $\mathrm{Zu}$ standsspektren einer chiralen und einer nicht-chiralen Theorie.

"Simply put, T-duality is a spacetime parity operation on just one side of the world sheet, and so reverses the relative chiralities of the rightand left-moving ground states. If we begin with the IIA theory and take the compactification radius to be small, we obtain the IIB theory at large radius and vice versa." (Polchinski (2000a) 137)

Anschaulich entspricht die T-Dualität dem Austausch von Windungs- und Oszillationszuständen beim Übergang von einer Beschreibung zur anderen.

$95 \quad$ Siehe etwa Giveon / Porrati / Rabinovici (1994). 
Eine ihrer Konsequenzen besteht nach gängiger Auffassung der Stringtheoretiker in der Etablierung einer kleinsten Länge für die Stringtheorien: Verkleinert man für eine Stringtheorie A den Kompaktifizierungsradius unter die Stringlänge $1_{S}$, so entspricht das Resultat hinsichtlich der Stringzustände einer Beschreibung auf der Grundlage der zu A T-dualen Theorie B mit einem Kompaktifizierungsradius grösser als ${ }_{S}$. Die T-Dualität spiegelt insofern Prozesse, die sich scheinbar im Längenbereich unterhalb von ${ }_{S}$ abspielen, grundsätzlich auf Prozesse im Längenbereich oberhalb von ${ }_{\mathrm{S}}$. Versucht man innerhalb des Stringansatzes Abstände zu beschreiben, die kleiner sind als die Stringlänge, so führt dies nur dazu, das ein Alternativkonstrukt, das von Abständen handelt, die grösser sind als die Stringlänge, qua Äquivalenz die Beschreibung genauso gut übernehmen kann. Das heisst, dass unterhalb von $1_{S}$ keine Prozesse stattfinden, die nicht auch schon oberhalb von $1_{S}$ existieren. Und genau dies lässt sich nun so lesen, dass für die Stringtheorien mittels der T-Dualität die Stringlänge $1_{S}$ als kleinster Abstand festgeschrieben wird.

Eine Verallgemeinerung der T-Dualität von eindimensionalen zylindrischen Kompaktifizierungen auf sechsdimensionale Calabi-Yau-Mannigfaltigkeiten ist die Spiegelsymmetrie. ${ }^{96}$ Sie besteht in der Identität der Zustandsspektren des String für unterschiedliche Raumzeittopologien hinsichtlich der kompaktifizierten Dimensionen:

"Mirror symmetry [...] is another well known example of a duality. In this case, two topologically distinct Calabi-Yau compactification of string theory give rise to identical physical models." (Greene (1997) 4)

96 Siehe etwa Aspinwall / Greene / Morrison (1994) oder Strominger / Yau / Zaslov (1996). 


\section{S-Dualität}

Wesentlich weitreichender in ihren Konsequenzen als die T-Dualität ist die S-Dualität ("strong-weak duality"), da sie es ermöglicht, Konsequenzen des Stringansatzes abzuleiten, die über den perturbativen Kontext hinausgehen. ${ }^{97}$ Die S-Dualität etabliert Äquivalenzen der Zustandsspektren zwischen Bereichen schwacher Kopplung bei einer Stringtheorie A und solchen starker Kopplung bei einer Theorie B.

Die effektive Kopplungsstärke $\mathrm{g}_{\mathrm{S}}$ der Stringtheorien ist, wie schon erwähnt, durch den Erwartungswert des Dilaton-Feldes gegeben: $g_{S}=e^{\langle\phi\rangle}$. Dieser Erwartungswert muss nicht notwendigerweise klein sein. Der perturbative Stringansatz funktioniert aber nur bei schwacher Kopplung (kleinem $g_{S}$ ). Ansonsten divergieren die störungstheoretischen Entwicklungen. Mit den perturbativen Stringtheorien lässt sich also für eine starke Kopplung (grosses $g_{s}$ ) keine Beschreibung der Stringdynamik erreichen. Hier bringt nun die S-Dualität zumindest partielle Abhilfe. Da sie Äquivalenzen der Zustandsspektren zwischen Bereichen starker Kopplung bei einer Stringtheorie A und solchen schwacher Kopplung bei einer Theorie B etabliert, ist es, wenn die perturbativen Prozeduren für eine Theorie A infolge starker Kopplung nicht mehr zum Einsatz kommen können, mit ihrer Hilfe möglich, diese durch die perturbativen Prozeduren einer zu ihr S-dualen Theorie B bei schwacher Kopplung zu ersetzen. Beide führen unter der Bedingungen $\mathrm{g}_{\mathrm{SA}}=1 / \mathrm{g}_{\mathrm{SB}} \mathrm{zu}$ identischen Resultaten hinsichtlich der $\mathrm{Zu}$ standsspektren. ${ }^{98}$ Man kann also den nicht-perturbativen Bereich der einen Theorie mit Hilfe der S-Dualität durch den perturbativen Bereich einer zweiten Theorie erfassen.

Wie lässt sich aber die für diese Ersetzung erforderliche S-Dualität selbst nachweisen, wenn der perturbative Stringansatz nur bei schwacher Kopp-

$97 \quad$ Die S-Dualität ist die ausschlaggebende Entdeckung, die zur zweiten Superstring-Revolution führte. Sie ist eine Verallgemeinerung der Montonen-Olive-Dualität und weiterer Dualitäten innerhalb der Elektrodynamik und der statistischen Mechanik. 98 Der für die S-Dualität relevante Übergang zwischen Theorie A mit starker Kopplung und Theorie B mit schwacher Kopplung entspricht also gerade dem Übergang zwischen $\left\langle\phi_{\mathrm{A}}>\right.$ und $-<\phi_{\mathrm{B}}>$. 
lung funktioniert? Der Nachweis der S-Dualität müsste dem Nachweis der Identität der Zustandsspektren für eine Theorie bei starker und eine andere Theorie bei schwacher Kopplung entsprechen. Wie lässt sich aber der Bereich starker Kopplung erschliessen, aus dem sich erst der Nachweis für die S-Dualität ergibt? - Es ist die Supersymmetrie, die hier entscheidend ist. ${ }^{99}$ Für supersymmetrische Theorien lässt sich der Bereich der starken Kopplung zumindest punktuell über die nicht-perturbativen BPS-(Bogomol'nyi-Prasad-Sommerfield)-Zustände erschliessen. Die Energie ist für diese Zustände infolge der Supersymmetrie vollständig durch die Ladung festgelegt, also ohne den Einsatz perturbativer Prozeduren ermittelbar. Sie ist eine Folge der Symmetrie und nicht von der Dynamik abhängig. ${ }^{100}$ Mit den BPS-Zuständen lässt sich der nicht-perturbative Bereich aber eben nur punktuell erschliessen. Tatsächlich ist die S-Dualität daher bisher nur eine für wenige Spezialfälle nachweisbare Vermutung.

"[...] since duality typically relates a strongly coupled string theory to a weakly coupled string theory, and since at present there is no independent description of string theory at strong coupling, we cannot prove duality." (Sen (1998) 3)

Es ist also zumindest Vorsicht geboten hinsichtlich der Verallgemeinerungen, die sich aus der S-Dualität ergeben könnten:

"[...] although these duality relations are quite impressive, we may still challenge many of these results because of their lack of rigor. We have only established the S-duality transformations to lowest order in

$99 \quad$ Es ist damit jedoch bis zu einem gewissen Grade fragwürdig, ob die S-Dualität für die Beschreibung unserer Welt wirklich relevant ist. Denn sie gilt wie die BPSZustände, auf die sich ihre Ableitung beruft, eigentlich nur für Theorien mit ungebrochener Supersymmetrie:

"In realistic theories the degeneracy is removed and the moduli made massive by supersymmetry breaking." (Polchinski (1996) 16)

Für unsere Welt muss aber die Supersymmetrie notwendigerweise gebrochen sein, sonst würden wir supersymmetrische Partnerteilchen mit identischer Masse zu unseren bekannten Teilchen vorfinden.

100 Siehe Polchinski (1996) und (1999). Beispielsweise gilt für Theorien mit ungebrochener Supersymmetrie: Jeder BPS-Zustand mit Ladung Null hat auch die Energie Null. Alle BPS-Zustände mit Ladung Null sind also degeneriert. Jeder BPS-Zustand entspricht einem der skalaren Moduli-Felder. Aufgrund der Antikommutatorbeziehungen gibt es keinen Zustand mit geringerer Energie. BPS-Zustände mit Ladung und Energie Null sind notwendigerweise Grundzustände des Systems. 
the effective theories. Although this is still an unsolved problem, we have confidence in these results because of the number of self-consistency checks we can make, the most compelling being the analysis of BPS saturared states and p-branes." (Kaku (1999) 480)

Einige Beispiele für die S-Dualität sind aber bereits einigermassen überzeugend etabliert: Für eine flache sechsdimensionale Raumzeit entspricht der Grenzwert der starken Kopplung der Typ-IIA-Theorie der schwachen Kopplung für die heterotische Theorie. ${ }^{101}$ Für eine flache zehndimensionale Raumzeit entspricht der Grenzwert der starken Kopplung der Typ-ITheorie (unorientierte offene Strings) der schwachen Kopplung für die heterotische SO(32)-Theorie (orientierte geschlossene Strings). Damit ergibt sich eine Dualität zwischen einer Theorie mit unorientierten offenen Strings und einer Theorie mit orientierten geschlossenen Strings. Ebenso für eine flache zehndimensionale Raumzeit ergibt sich eine Äquivalenz zwischen dem Grenzwert der starken Kopplung der Typ-IIB-Theorie und der schwachen Kopplung der selben Theorie. Für die Typ-IIB-Theorie ist also für $\mathrm{g}_{\mathrm{S}}$ und für $1 / \mathrm{g}_{\mathrm{S}}$ das Zustandsspektrum gleich.

Als Überraschung mit weitreichenden Konsequenzen zeigte sich zudem: ${ }^{102}$ Für eine flache zehndimensionale Raumzeit und eine nun für den Fall starker Kopplung hinzutretende, kreisförmig aufgerollte, elfte Dimension ist sowohl der Grenzwert der starken Kopplung der Typ-IIA-Theorie, als auch der der heterotischen $\mathrm{E}_{8} \times \mathrm{E}_{8}$-Theorie identisch mit dem der schwachen Kopplung für die elfdimensionale "Supergravity"-Theorie, ${ }^{103}$ eine supersymmetrische Quantenfeldtheorie der Gravitation, welche in den siebziger und achtziger Jahren intensiv diskutiert wurde und zeitweise als Anwärter für eine Beschreibung der Quantengravitation galt. Sie hat sich jedoch als nicht renormierbar und nicht chiral herausgestellt. ${ }^{104}$ Obwohl sie, wie heute klar ist, nicht als fundamentale Theorie der Quantengravitation angesehen werden kann, kann sie jedoch unter Umständen als effektive Niederenergienäherung einer fundamentaleren Theorie infrage kommen. Immerhin verfügt die Supergravity über keine dimensionslosen Parameter.

\footnotetext{
101 Dies wurde 1994 von Christopher M. Hull und Paul K. Townsend entdeckt.

102 Siehe Townsend (1995).

103 Siehe Cremmer / Julia / Scherk (1978).

104 Chiralität ist für punktförmige Entitäten - von solchen geht, ebenso wie die Quantenfeldtheorien, auch die Supergravity aus - in 11 Dimensionen nicht formulierbar.
} 
Widerspricht aber das Auftauchen einer elften Dimension im Rahmen der S-Dualität zwischen perturbativen Stringtheorien und der alten Supergravity-Theorie nicht der Festlegung des Stringansatzes auf zehn raumzeitliche Dimensionen? - Nicht, wenn man berücksichtigt, dass diese Festlegung erst einmal nur im Rahmen des perturbativen Ansatzes Gültigkeit hat und sich mit der S-Dualität gerade eine Erweiterung in den nichtperturbativen Bereich ergibt!

"[...] the 10-dimensional Type IIA [...] is actually an 11-dimensional theory in disguise!" (Kaku (1999) 467)

\section{M-Theorie}

Die sich mit der S-Dualität abzeichnende elfte Dimension der Raumzeit wird von den Stringtheoretikern als eines der Anzeichen für eine - meist M-Theorie genannte - elfdimensionale nicht-perturbative Theorie hinter den zehndimensionalen perturbativen Stringtheorien angesehen. ${ }^{105}$ Man geht davon aus, dass die elfdimensionale Supergravity eine Niederenergienäherung dieser nicht-perturbativen Theorie ist. ${ }^{106}$

"We are led to postulate the existence of an entirely new 11-dimensional theory, called M-theory. Our conclusion is then as follows: there

105 Siehe etwa Duff (1996), Townsend (1995), (1996), Schwarz (1996), (1997), Green (1998), Sen (1998), (1998b), Mukhi (1997) sowie Lerche (2000).

106 Die Besonderheit einer elfdimensionalen Theorie besteht darin, dass elf Dimensionen gerade das Maximum sind, wenn man Zustände mit Spins über 2 vermeiden will:

"Eleven dimensions is an interesting number. This is the maximum in which supersymmetry is possible - beyond eleven the massless multiplets would contain spins higher than two, something which seems to be impossible in a consistent theory." (Polchinski (1996) 24)

Eine Dimensionszahl über elf scheint für supersymmetrische Theorien nicht möglich zu sein:

"It is not possible to construct [supergravity] theories in dimensions $d>11$ since there is no possibility of matching bosonic and fermionic degrees of freedom." (Alvarez-Gaumé / Vázquez-Mozo (1992) 9) 
exists a new 11-dimensional theory, called M-theory, containing 11dimensional supergravity as its low-energy limit, which reduces to Type IIA string theory (with Kaluza-Klein modes) when compactified on a circle. Specifically, the strong coupling limit of Type IIA is Mtheory." (Kaku (1999) 467f)

Die M-Theorie ist jedoch bisher nicht mehr als Programm und Spekulation. Immerhin lässt sich plausibel machen, wieso die elfte Dimension gerade im Rahmen der S-Dualität in Erscheinung tritt. Sie wird nämlich erst beim Übergang in den nicht mehr perturbativ erschliessbaren Bereich der Stringtheorien wirksam. Für kleine Erwartungswerte des Dilatonfeldes, die gerade die Voraussetzung für die Anwendung perturbativer Prozeduren sind, spielt sie keine Rolle. Sie ist ein grundsätzlich nicht-perturbatives Phänomen und tritt erst für den Bereich starker Kopplung in Erscheinung. Das liegt darin begründet, dass die zusätzliche elfte Dimension sich als metrische Transformation der effektiven Kopplungskonstante der Stringtheorien, also des Erwartungswerts des Dilaton-Feldes, ansehen lässt.

"The $D=10$ dilaton, which governs the strength of the string coupling, is just a component of the D=11 metric." (Duff (1996) 3)

Daher gibt es in der elfdimensionalen Theorie auch kein Dilaton-Feld mehr. Es ist im Rahmen der dimensionalen Erweiterung in die Metrik eingegangen. Das Dilaton-Feld wird zum Teil der Metrik der Raumzeit. Die effektive Kopplungsstärke entspricht dann der Ausdehnung der eingerollten elften Dimension und ist selbst ein metrisches Phänomen.

"We can [...] see why physicists missed this rather simple correspondence for many years. Because the coupling constant grows with the radius of compactification, perturbation theory will never reveal this eleventh dimension to any finite order in the expansion. This correspondence between 11- and 10-dimensional physics is inherently a nonperturbative one." (Kaku (1999) 469)

Hier wird exemplarisch ein Problem hinsichtlich der Interpretation der Kompaktifizierungsmodi innerhalb des Stringansatzes deutlich: Welche masselosen Zustände des String tatsächlich als Felder und welche als interne Komponenten der Metrik und Topologie der Raumzeit zu sehen sind, ist im Stringansatz insofern oft Interpretationssache, als zum Teil völlig 
verschiedene Darstellungsweisen qua Dualitäten äquivalent sind. ${ }^{107}$ Man kann (i) die hinsichtlich des raumzeitlichen Geschehens realistische Perspektive einnehmen, dass die raumzeitliche Metrik und Topologie der kompakten Dimensionen die Zustände tatsächlich dynamisch festlegt, aber ebenso (ii) die strukturalistische Perspektive, dass sie nur eine geometrische Metapher für die Parametrisierung der Zustandsspektren liefert - oder schliesslich gar (iii) die geometrodynamische Auffassung, dass die $\mathrm{Zu}$ stände nur Ausdruck der raumzeitlichen Metrik und Topologie der kompakten Dimensionen sind. ${ }^{108}$

Die sich in den S-Dualitäten zeigende elfte Dimension hat aber nach Auffassung der Stringtheoretiker noch weitere Konsequenzen. Vor allem betrifft dies die für die M-Theorie zu erwartenden basalen Konstituenten. In der elfdimensionalen M-Theorie sollten die Strings der perturbativen Stringtheorien, wie man vermutet, als zylindrisch eingerollte zweidimensionale Membrane auftreten, ${ }^{109}$ was für die mathematische Modellierung dieser Theorie, nach den Erfahrungen mit den alten Supergravity-Ansätzen, immerhin Schwierigkeiten bedeuten könnte:

"There was at one time an effort to define eleven-dimensional supergravity as a theory of fundamental membranes; this was one of the roots of the name M-theory. This had many difficulties, the most immediate being that the world-sheet theory is nonrenormalizable." (Polchinski (2000a) 216)

Insbesondere ist völlig unklar, wie sich die Dynamik dieser Membrane quantisieren lassen sollte. ${ }^{110}$

\footnotetext{
107 Siehe Schwarz (2000), insb. S. 39.

108 Hier zeigt sich, dass es vom Stringansatz zur Wheelerschen Quantengeometrodynamik möglicherweise gar nicht so weit ist.

109 Dass die Membrane der M-Theorie innerhalb der zehndimensionalen perturbativen Stringtheorien als eindimensionale Objekte behandelt werden, ist nach gängiger Auffassung als Näherung für den Fall schwacher Kopplung bzw. niedriger Erwartungswerte des Dilatonfeldes anzusehen. Bei dieser Näherung lässt sich über die kompakte elfte Dimension hinwegsehen, da ihre Ausdehnung für den perturbativen Fall vernachlässigbar ist. Der perturbative Bereich kennzeichnet sich gerade durch kleine effektive Kopplungsparameter, also kleine Erwartungswerte des Dilatonfeldes, was innerhalb der elfdimensionalen Theorie nichts anderes bedeutet als eine geringe Ausdehnung für die kompakte elfte Dimension.
}

$110 \quad$ Siehe Kap. 4.1. 
"The fact that the string theory is so simple to quantize can be traced to the fundamental fact that the Hamiltonian is quadratic in the string variables; this means that is decomposes into an infinite series of free particles. A vast collection of vacuum solutions to string theory can be constructed because, in essence, it is a free theory. However, this simplicity breaks down completely when we analyze membranes in $M$ theory. We will find that the Hamiltonian is now quartic, making the quantization intractable. In contrast to the simplicity of string theory, there is still no satisfactory method for quantizing free membranes." (Kaku (1999) 62)

Wie man heute vermutet, ist mit der M-Theorie ein Übergang zu einem ganzen Spektrum von höherdimensionalen Grundelementen verbunden: nicht nur zu Membranen, sondern ebenso zu den noch zu erörternden $\mathrm{p}$ Branen und D-Branen. ${ }^{111}$ Dann stellt sich natürlich sofort die Frage nach den hinter diesen Grundelementen stehenden Prinzipien:

"The ideal definition of string/M/F/...-theory would have a sort of 'manifest duality' in which every object which could become fundamental in any limit was included as a fundamental degree of freedom. However, there is a bewildering variety of candidate fundamental degrees of freedom, especially after compactification, and such a description might well require intractable constraints among them. I One might look for some general 'principle of construction' that builds up all possible extended objects as composite objects. Perhaps the appropriate constituent degrees of freedom have not even made their appearance yet!" (Douglas (1996) 26)

Aber auch wenn hinsichtlich dieser Prinzipien vollkommene Unklarheit herrscht: Für die postulierte M-Theorie spricht, nach Auffassung der Stringtheoretiker, nicht nur das Auftreten einer zusätzlichen elften Dimension für den Fall starker Kopplung im Rahmen der S-Dualität, sondern das Auftreten der Dualitäten überhaupt. Dieses lässt sich, nach gängiger Auffassung, als Anzeichen für eine durchgängige Verbindung zwischen den perturbativen Stringtheorien werten - und mithin für eine nicht-perturbative Theorie hinter diesen perturbativen Ansätzen:

111 Siehe Kap. 2.4. sowie Townsend (1995a). 
"It can now be explicitly shown that by compactifying any one of the five theories on a suitable manifold, and then un-compactifying it in another manner, one can reach any other of the five theories in a continuous way." (Lerche (2000) 27)

Das Netz der Dualitäten

$I I B<-\mathrm{T}->I I A<-\mathrm{S}->$ Supergravity <-S-> $E_{8} \times E_{8}<-\mathrm{T}->S O(32)<-\mathrm{S}->I$ $>\mathrm{S}<$

und die mit ihm verbundene Einsicht in die letztendliche gemeinsame Grundlage der unterschiedlichen perturbativen Superstringtheorien deuten nach Ansicht der Stringtheoretiker gerade darauf hin, diese perturbativen Theorien als unterschiedliche Näherungen einer grundlegenderen nichtperturbativen Theorie zu verstehen.

"For string theory the change in viewpoint is perhaps even wider and includes the discovery that there is only one theory. I For weak coupling the five string theories - and the wild card, eleven-dimensional supergravity - are all different. That is why they have been traditionally understood as different theories. Understanding them as different limits to one theory requires understanding what happens for strong coupling. / The novelty of the last couple of years, in a nutshell, is that we have learned that the strong-coupling behavior of supersymmetric string theories and field theories is governed by a web of dualities relating different theories. When one description breaks down because a coupling parameter becomes large, another description takes over. / [...] we learn that the different theories are all one. The different supertheories studied in different ways in the last generation are different manifestations of one underlying, and still mysterious, theory, sometimes called M-theory, where $M$ stands for magic, mystery or membrane, according to taste. This theory is the candidate for superunification of the forces of nature. It has eleven-dimensional supergravity and all the traditionally studied string theories among its possible low-energy manifestations." (Witten (1997) 32)

Alle perturbativen Stringtheorien entsprechen dieser Auffassung zufolge einer spezifischen "Koordinatenwahl" im Parameterraum dieser grund- 
legenderen, aber noch unbekannten M-Theorie, für die man sich eine einheitliche Beschreibung für die Zukunft erhofft.

"Already, M-theory can unify the five different superstring theories into a single theory. Ultimately, there may be a single equation (perhaps no more than an inch long) which will unify the entire theory." (Kaku (1999) 5)

Aber von einer Grundgleichung für die M-Theorie ist der Stringansatz noch weit entfernt:

"The complete action of M-theory is unknown." (Kaku (1999) 458)

"[...] the central defining principle of string theory is not known." (Polchinski (1996) 9)

Man kennt bestenfalls Niederenergienäherungen und perturbative Grenzfälle dieser Theorie:

"We know only its low-energy part, which is 11-dimensional supergravity. A present there is no known way to systematically derive the entire nonpolynomial theory. Also, we know very little about the quantization of these membranes and 5-branes in 11 dimensions, and hence cannot make definitive statements about their interactions." (Kaku (1999) 468)

In ihren nicht-perturbativen Eigenschaften und hinsichtlich der Dynamik der vermuteten höherdimensionalen Konstituenten ist die M-Theorie noch völlig unbekannt. Und es ziemlich unklar wie sich die mit ihr anbahnenden konzeptionellen Probleme mathematisch meistern lassen sollen:

"Unless M-theory is quantized, we will never understand its spectra and rigorously understand its properties. Unfortunately, even simple membrane actions cannot be quantized with known techniques." (Kaku (1999) 543)

Angesichts des Anspruchs, mit der M-Theorie die fundamentalste physikalische Theorie zu entwickeln, zeichnet sich günstigerweise immerhin schon ab, dass diese vermutlich ohne parametrische Kopplungskonstante 
auskommen wird. Denn es gibt, wie schon erwähnt, in der M-Theorie kein Dilaton-Feld, welches die Wechselwirkungsstärke bestimmen würde, da dieses im Übergang vom perturbativen auf den nicht-perturbativen Bereich als elfte Dimension in die Metrik und Topologie der Raumzeit einfliesst.

"What makes M-theory at once intriguing and yet difficult to analyse is that in $D=11$ there is neither dilaton nor moduli and hence the theory is intrinsically non-perturbative." (Duff (1996) 1)

Damit fallen jedoch vermutlich auch alle mathematischen Prozeduren, die gemeinhin zur Beschreibung von Wechselwirkungsprozessen eingesetzt werden, für die M-Theorie weg:

"We know little about the eleven-dimensional theory. Its low energy physics must be described by $d=11$ supergravity, but it has no dimensionless parameter in which to make a perturbation expansion. At energies of order $M_{11}$ neither supergravity nor string theory is a useful description." (Polchinski (2000a) 199)

Mit der sogenannten Matrix-Theorie liegt immerhin inzwischen vielleicht ein erster Schritt zur nicht-perturbativen Erschliessung der M-Theorie vor. ${ }^{112}$

"Matrix Theory is supposed to be the Discrete Light Cone Quantization (DLCQ) of M-theory. The spectrum of the DLCQ theory diverges more rapidly at large energy than that of the limiting, decompactified theory, for 9 or fewer asymptotically flat dimensions. At $D=5$ the $D L C Q$ spectrum blows up faster than an exponential of light cone energy and we don't know how to define it. It is of greatest interest to work out the form of the decompactified quantum theory." (Banks (2003) 29)

Aber auch die Matrix-Theorie kann keine umfassende Gültigkeit für sich beanspruchen. Sie ist überhaupt nur unter spezifischen Bedingungen einsetzbar, und auch dann nicht ohne Probleme:

112 Siehe etwa Banks (1998) (2001a), Banks et al. (1997), Bigatti / Susskind (1997), Bilal (1999), Taylor (2001). 
"Not only is Matrix Theory awkward to use, but (more fundamentally) it seems to be applicable to only a limited class of quantum vacua. In particular, it does not seem able to describe realistic vacua in which all but four dimensions are compactified." (Schwarz (1998) 6)

Insbesondere ist auch die Matrix-Theorie, wie schon die perturbativen Stringtheorien, keine hintergrundunabhängige Theorie. ${ }^{113}$ Dies steht jedoch im Widerstreit zur Annahme, dass die M-Theorie, wenn sie als abschliessende Theorie der Quantengravitation infrage kommen soll, eine nicht-perturbative Theorie ohne Hintergrundraumzeit sein sollte: ${ }^{114}$

"If $M$ theory is to be a unification of all the different background dependent string theories, and hence treat them all on an equal footing, it cannot be formulated in terms of any single spacetime background. Hence, we expect that $M$ theory must be a background independent theory." (Smolin (2005) 28)

Das Hauptproblem bei der Formulierung der M-Theorie, ob als MatrixTheorie oder in anderer Form, besteht aber eindeutig vor allem in der Schwierigkeit, dass die der Theorie zugrundeliegenden Prinzipien schlichtweg unbekannt sind. ${ }^{115}$ Dieses Problem wird vor allem im Vergleich mit der Allgemeinen Relativitätstheorie und den Quantenfeldtheorien deutlich. Erstere liess sich auf der Grundlage des Äquivalenzprinzips bzw. des Prinzips der allgemeinen Kovarianz entwickeln, letztere basieren ausnahmslos auf Eichinvarianzen.

"[...] both general relativity and Yang-Mills theory are mature theories: they both can be formulated from first principles, which stresses the geometry and the physical assumptions underlying the theory." (Kaku (1999) 6)

Vielleicht werden sich diese Probleme irgendwann lösen lassen. Vielleicht gibt es aber auch gar keine einheitliche Theorie hinter den durch Dualitäten verbundenen Ansätzen:

\footnotetext{
113 Siehe Smolin (2003).

114 Das Problem der Hintergrundraumzeit wird ausführlich in Kap. 6. zu erörtern sein.

115 Siehe hierzu auch Kap. 6.
} 
"I believe that the most cogent summary of what was achieved by the String Duality Revolution is the statement that what we used to call String Theory is really just the collection of Supersymmetric Quantum Theories of Gravitation." (Banks (2003) 8)

Das Interessanteste, was sich über die M-Theorie sagen lässt, ist, dass sie als regulatives Ideal den Stringansatz weiterträgt, obwohl es sie gar nicht als explizites Konstrukt gibt, sondern nur als Summe der diversen Kommentare, mit denen sich die Stringtheoretiker auf sie beziehen (und für die das folgende Zitat das vorerst letzte Beispiel liefern soll):

"The remarkable thing about this kind of reasoning is that it works even though we don't understand how to formulate the $M$ theory as a quantum theory." (Schwarz (1996) 1)

Die M-Theorie wird als Anwärter auf die letzte fundamentale physikalische Theorie gehandelt, ohne tatsächlich zu existieren. Wenn sie in irgendeiner Hinsicht wirklich gut funktioniert, dann als Mythos. 


\subsection{Dirichlet-Branen und Bran-Welten}

Schon im Rahmen der Erörterung der Kompaktifizierung der überzähligen Raumdimensionen war die Rede davon, dass die Raumzeit im Stringansatz grundsätzlich auch Singularitäten enthalten könnte. Bei der tentativen Erschliessung des Übergangs vom perturbativen zum nicht-perturbativen Bereich ist dann im Stringansatz zunehmend deutlich geworden, dass die Stringdynamik höherdimensionale Entitäten, topologische Defekte und solitonische Zustände einschliessen kann und diese den nicht-perturbativen Bereich wahrscheinlich sogar dominieren:

"String compactifications on manifolds $X$ are not only complex because of the large moduli spaces they generically have, but also because the spectrum of physical states becomes vastly more complicated. In fact, when going down in the dimension by compactification, there is a dramatic proliferation of non-perturbative states. / The reason is that string theory is not simply a theory of strings: there exist also higher dimensional extended objects, so called 'p-branes', which have p space and one time dimension [...]. In the light of duality [...] we know that there is no absolute distinction between elementary or solitonic objects." (Lerche (2000) 24)

Der Stringansatz birgt also - spätestens wenn Zusammenhänge in Erscheinung treten, die über den rein perturbativen Kontext hinausweisen Entitäten, die das einfache Bild eines Zustandekommens aller dynamischen Zustände ausschliesslich auf der Basis von Strings und ihrer Dynamik deutlich überschreiten. Im Rahmen der Dualitäten zwischen verschiedenen Beschreibungsweisen etwa werden die fundamentalen Entitäten der einen Beschreibungsweise zu abgeleiteten Entitäten innerhalb der dazu dualen Beschreibungsweise, und umgekehrt. Es sind also nicht immer die basalen Strings der perturbativen Stringtheorien, die die Rolle der fundamentalen Entitäten innerhalb dieser unterschiedlichen Ansätze spielen.

"In addition to the fundamental strings, various string theories have in their spectra one-dimensional objects which are either smooth solitons or D-branes. At weak coupling these are much heavier than the fundamental strings, but at strong coupling they are much lighter 
(again this guaranteed by the BPS formula). In this limit it is natural to reinterpret the theory with the soliton or D-brane being the fundamental string." (Polchinski (1996) 22)

In dieser Hinsicht ist es zumindest fragwürdig, ob die Bezeichnung "Stringtheorie" noch vollends angemessen ist.

"[...] since string theory contains degrees of freedom with more (or less) than one spatial dimension, and since in certain circumstances it is these degrees of freedom which dominate the low-energy dynamics [...], maybe the term 'string' theory is a historical misnomer." (Greene (1997) 7)

Aber mit Bezeichnungen gehen nicht notwendigerweise ontologische Postulate einher. Es sind bei weitem noch nicht alle Entitäten bekannt, die im Rahmen der Stringtheorien und ihrer nicht-perturbativen Erweiterungen auftreten können. Dies ist nicht zuletzt darauf zurückzuführen, dass der nicht-perturbative Bereich der Stringtheorien bisher nur ansatzweise erschlossen werden konnte und die zugrundeliegenden Prinzipien bisher völlig unbekannt sind.

"[...] every indication is that the string description is useful only [...] [when] the string coupling becomes weak. In the center of the parameter space, not only do we not know the Hamiltonian but we do not know what degrees of freedom are supposed to appear in it. It is likely that they are not the one-dimensional objects that one usually thinks of in string theory; it is more likely that they are the coordinate matrices of the D-Branes." (Polchinski (1999) 21) ${ }^{116}$

$\mathrm{Zu}$ den wichtigsten der mittlerweile bekannten Entitäten, die für die Stringtheorien beim Übergang in den nicht-perturbativen Bereich auftreten, gehören p-Branen und D-Branen. p-Branen ${ }^{117}$ sind Lösungen des Stringansatzes, für welche die Energie auf eine p-dimensionale, räumliche Hy-

116 Man vermutet, dass die im vorausgehenden Abschnitt erwähnte Matrix-Theorie, mittels derer eine Annäherung an die mysteriöse M-Theorie erreicht werden soll, gerade die Dynamik von D-Branen, von denen sogleich die Rede sein wird, in Form von Koordinaten-Matrizen erfasst. Mathematische Grundlage ist eine nicht-kommutative Geometrie.

117 Siehe etwa Strominger (1996) und Witten (1996a). 
perfläche konzentriert ist. Sie lassen sich nicht aus ausschliesslich perturbativen Ansätzen ableiten, sondern erst im Rahmen einer zumindest ansatzweise nicht-perturbativen Beschreibung. p-Branen dehnen sich in $p$ räumlichen Dimensionen (tangentiale Dimensionen) aus und können sich in allen anderen räumlichen Dimensionen (transversale Dimensionen) bewegen bzw. lokalisieren lassen. Sie sind invariant unter Translation entlang der tangentialen räumlichen Dimensionen und der Zeit. Bei Entfernung von der Bran in der transversalen Richtung nähern sich die Zustandswerte sehr schnell an die jeweilige Vakuumlösung an. ${ }^{118}$ Die zulässigen räumlichen Dimensionen $\mathrm{p}$ sind für die IIA-Theorie gerade und für die IIBTheorie ungerade. - Und manche p-Branen sind Dirichlet-Branen, kurz: DBranen.

\section{D-Branen}

D-Branen sind dynamische Raumzeit-Submannigfaltigkeiten, die sich dadurch charakterisieren lassen, dass offene Strings auf ihnen enden: ${ }^{19}$

"D-branes are topological defects on which the ends of a string can be trapped." (Polchinski (1996) 22)

Die Anbindung an die D-Bran ist formal dadurch gegeben, dass für die Stringendpunkte transversal zur Bran sogenannte "Dirichlet-Randbedingungen" gelten. Diese entsprechen gerade einer Fixierung der Endpunkte der Strings auf der Bran. Tangential zur Bran können sich die Enden der Strings (entsprechend den hierfür geltenden "Neumann-Randbedingun-

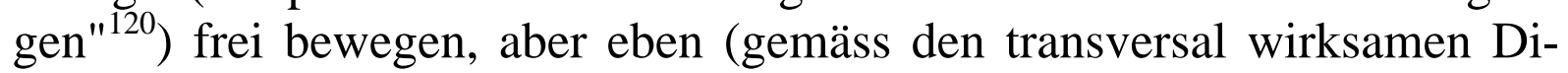
richlet-Randbedingungen) nicht von ihr weg.

118 Sogenannte "Schwarze p-Branen" sind p-Branen mit Ereignishorizonten. Sie sind invariant unter Translation entlang der tangentialen Dimensionen und der Zeit. Entlang der transversalen Dimensionen haben sie die geometrische Struktur Schwarzer Löcher.

119 Siehe etwa Bachas (1996) und (1997), Polchinski (1995) und (1996a) sowie Polchinski et al. (1996).

120 Dirichlet- und Neumann-Randbedingungen erschöpfen die Möglichkeiten der Festlegung für die Stringendpunkte. 
"It was once thought that Dirichlet boundary conditions, where the derivative of the string variable is a nonzero constant, lead to unphysical strings, since the endpoints are now fixed in space and time, terminating on a stationary hyperplane. When we discuss M-theory, however, we will find that these hyperplanes can actually move in space and time, oscillating like membranes (called D-branes). These D-branes, we will see, are essential in understanding the solitonlike solutions of string theory." (Kaku (1999) 56)

Die D-Bran definiert sich über die infolge der Dirichlet-Randbedingungen an ihr ankoppelnden offenen Strings. Die Integration der Dirichlet-Randbedingungen führt zur Spezifizierung der Raumzeitpunkte, an denen Strings ankoppeln. Sie führt zur Festlegung der D-Bran. Die Dynamik der D-Bran (Oszillationen, Translationen, Wechselwirkung mit anderen DBranen und Strings) wird durch die Strings, die auf ihr enden, vollständig bestimmt.

D-Branen kommen, wie vermutet wird, infolge nicht-perturbativer Effekte zustande und treten in den Stringtheorien des Typs I, IIA und IIB als quasiklassische, dynamisch stabile Lösungen in Erscheinung. - Wie können aber D-Branen, die sich dadurch definieren, dass offene Strings auf ihnen enden, für die Theorien vom Typ IIA und IIB existieren, die im Gegensatz zur Theorie vom Typ I nur geschlossene Strings enthalten? Die überraschende Antwort lautet: In den Theorien vom Typ IIA und IIB gibt es, im Gegensatz zu dem Bild, das sich für den perturbativen Kontext einstellt, offene Strings - allerdings nur bei Anwesenheit von D-Branen, also nur für den nicht-perturbativen Fall.

"In type IIA or type IIB superstring theories it is similarly natural to introduce D-branes on which open type I superstrings can end." (Bilal (1999) 7)

D-Branen liefern insbesondere eine Methode zur Implementierung von Ladungen in den Stringansatz. Denn D-Branen tragen als BPS-Zustände Ladungen, die alleine durch die Supersymmetrie bestimmt werden. ${ }^{121}$ Und

121 Die Energie dieser Zustände ist, wie schon erwähnt, infolge der Supersymmetrie ausschliesslich durch die Ladung festgelegt, also ohne den Einsatz perturbativer Prozeduren ermittelbar. Sie ist eine Folge der Symmetrie und nicht von der Dynamik abhängig. 
diese Ladungen sind nicht zuletzt auch die Ursache der Ankopplung offener Strings an die D-Branen - und damit der Existenz der D-Branen. ${ }^{122}$ Die Ladung einer D-Bran ist mit den Ladungen gleichzusetzen, die sich an den Enden der ankoppelnden offenen Strings befinden, die sich aber im Rahmen des perturbativen Stringansatzes nicht überzeugend rekonstruieren liessen. Diese sogenannten "Ramond-Ramond-Ladungen", die sich als Verallgemeinerung elektrischer und magnetischer Ladungen ansehen lassen, sind die Quellen entsprechender Eichfelder. ${ }^{123}$ Ihre Implementierung innerhalb des Stringansatzes durch die Einführung von D-Branen löst nicht zuletzt das bis dahin ungeklärte Problem der Quellen der Eichfelder:

"[...] there was the long-standing puzzle of what were the sources for the R-R fields. [...] out of the string variable [...] it was impossible to construct a source for the field." (Kaku (1999) 506)

"The discovery that $D$-branes carry $R$ - $R$ charges neatly ties together two loose ends. [...] it was argued [...] that the ordinary string states do not have $R$ - $R$ charges, but now we see that string theory does have a source for every gauge field." (Polchinski (2000a) 142)

Jede Dp-Bran, also jede D-Bran mit $\mathrm{p}$ räumlichen Dimensionen, ist die Quelle für ein $(\mathrm{p}+1)$-Form-Ramond-Ramond-Eichfeld. ${ }^{124}$

"D-p-branes are charged under p+1-form gauge potentials, in the same way that a 0-brane (particle) can be charged under a one-form gauge potential (as in electromagnetism)." (Aharony et al. (1999) 7)

Die zulässigen räumlichen Dimensionalitäten $\mathrm{p}$ von Dp-Branen hängen vom Typus der entsprechenden Stringtheorie ab: Für den Typ IIA ist p gerade und kann die Werte 0, 2, 4, 6 und 8 annehmen. Für den Typ IIB ist $p$ ungerade und kann die Werte -1, 1, 3, 5, 7 und 9 annehmen. ${ }^{125}$ Für den Typ

122 Siehe etwa Douglas (1996) und Giveon / Kutasov (1999).

123 Ramond-Ramond-Ladungen sind innerhalb des Stringansatzes die einzigen Ladungstypen, die mit der Lorentz-Invarianz kompatibel sind.

124 Eine p-Form ist ein antisymmetrischer Tensor mit p Indizes. p-Form-Eichfelder sind das Ergebnis einer Verallgemeinerung Abelscher Eichtheorien mit p-Form-Potential, (p-1)-Form Eichparameter und (p+1)-Form Feldstärke. Eine 1-Form ist beispielsweise ein Vektorpotential. Für $\mathrm{p}=0$ ergeben sich masselose Skalarfelder.

$125 \mathrm{D}(-1)$-Branen sind zeitliche Instantonen, denen formal die räumliche Dimensionszahl -1 zugewiesen wird: 
I sind es die Werte 1, 5 und 9. Eine D9-Bran ist raumfüllend und entspricht somit durchgängigen Neumann-Randbedingungen; offene Strings können sich für diesen Fall frei bewegen. Dies entspricht dem Spezialfall der Einführung von Ladungen im Chan-Paton-Verfahren, welches hiermit post hoc seine Motivation durch die Möglichkeit der Existenz von D9-Branen in der Stringtheorie von Typ I erfährt.

"[...] it is natural to interpret each Chan-Paton degree of freedom in the fully Neumann theory as a 9-brane filling spacetime." (Polchinski (2000a) 141)

Unter Berücksichtigung der Dualitätsbeziehungen zwischen den Theorietypen, für die sich D-Branen ergeben, verkompliziert sich die Sachlage noch einmal. Insbesondere verwandelt die T-Dualität Neumann-Randbedingungen in Dirichlet-Randbedingungen:

"Notice that T-duality converts a Neumann boundary condition into a Dirichlet condition. This, in turn, can explain how T-duality changes the properties of D-branes in Type IIA and IIB theories. We saw earlier that Type IIA(B) theory has even (odd) Dirichlet p-branes. If we make a T-duality transformation, then even and odd p-branes must turn into each other." (Kaku (1999) 520)

Die Grenzziehung zwischen Theorien mit offenen und solchen mit geschlossenen Strings wird mit den Dualitäten und der Einführung der DBranen irrelevant. ${ }^{126}$

"A (-1)-brane is a Dirichlet instanton, defined by Dirichlet conditions in the time direction as well as all spatial directions." (Polchinski / Chaudhuri / Johnson (1996) 27)

126 So lassen sich D-Branen möglicherweise auch als Pendants zu Schwarzen Löchern, respektive zu deren höherdimensionalen Verallgemeinerungen, interpretierten. Offene Strings liessen sich dann als geschlossene Strings deuten, von denen ein Teil in einer D-Bran verschwunden ist. Das könnte auch eine Erklärung dafür liefern, wieso es überhaupt offene und geschlossene Strings gibt. Geschlossene Strings liessen sich vielleicht als Quanten-Anregungen der Raumzeit auffassen; und offene Strings als geschlossene Strings, verbunden mit D-Branen. Siehe etwa Maldacena (1998). 


\section{Bran-Welten}

Wenn D-Branen die Quellen von Eichfeldern sind, so könnten, wie einige Stringtheoretiker vermuten, vielleicht auch die Eichfelder des Standardmodells ein Phänomen sein, das aus der Dynamik von D-Branen resultiert. ${ }^{127}$ Die Eichfelder würden dann an einer D-Bran ankoppeln und wären insofern nicht für die gesamte zehndimensionale Raumzeit präsent. Dies muss aber nicht nur für die Eichfelder gelten: D-Branen definieren sich gerade dadurch, dass offene Strings auf ihnen enden. Wenn unsere herkömmliche Materie und die Eichfelder der starken und der elektroschwachen Wechselwirkung aber als Zustände offener Strings anzusehen wären, so könnte dies bedeuten, dass die Materie und die Eichfelder unmittelbar an einer D-Bran ankoppeln und in ihrer Dynamik auf diese beschränkt sind. Nur die Gravitation, wenn sie durch die Zustände geschlossener Strings vermittelt würde, wäre ein Phänomen, welches die gesamte zehndimensionale Raumzeit beträfe. ${ }^{128}$

Vielleicht ist unser materielles Universum also eine (sich zeitlich entwickelnde) D3-Bran in einer zehndimensionalen Raumzeit. Die Materie und die Eichfelder wären an diese Bran gebunden. Nur die Gravitation würde sich im gesamten neundimensionalen Raum ausbreiten können. Und es könnte innerhalb der zehndimensionalen Raumzeit noch andere solche D-Branen unterschiedlicher Dimensionalität geben, vielleicht sogar weitere D3-Branen ähnlich der unseren. ${ }^{129}$

127 Einerseits ist jede Dp-Bran die Quelle für ein $(p+1)$-Form-Ramond-RamondEichfeld. Andererseits lässt sich zeigen, dass in dem Fall, in dem n Dp-Branen zusammentreffen oder parallel liegen und sich auf Entfernungen von weniger als der Stringlänge annähern, das entsprechende $(p+1)$-dimensionale Weltvolumen eine U(n)Eichsymmetrie aufweist.

128 Das könnte vielleicht auch Schwäche der Gravitation gegenüber den anderen Wechselwirkungen erklären.

129 Das sogenannte Horava-Witten-Szenario geht im Gegensatz zu dieser Idee von zwei zehndimensionalen Universen (bzw. zwei sich zeitlich entwickelnden 9-Branen) aus, die gemeinsam die elfdimensionale Raumzeit der M-Theorie aufspannen. Diese elfte Dimension zeigt sich, wie in Kap. 2.3. erörtert, erst für den Fall starker Kopplung, so dass der Übergang von schwacher zu starker Kopplung in diesem Bild einem Auseinanderdriften der zehndimensionalen Universen entspräche, welche die elfdimensionale Raumzeit der M-Theorie begrenzen. 
Das heisst aber auch, dass es vielleicht gar keine Kompaktifizierung gibt. Vielleicht sind alle neun räumlichen Dimensionen ausgedehnt und flach. ${ }^{130}$

"[...] in the $E_{8} x E_{8}$ case one can visualize the space-time as an 11d space-time with two 10d faces, which are sometimes referred to as 'end-of-the-world 9branes', since they have nine spatial dimensions. One of the $E_{8}$ gauge groups is associated to each face. In any case, at strong coupling the faces move apart and (away from the faces) the theory is described by the same 11d bulk theory that describes the IIA theory at strong coupling. This 11d theory is described in leading order in a low-energy expansion by 11 d supergravity, a classical field theory that was discovered almost 20 years ago. It is not yet known what is the correct algorithm that determines all the higher-dimension terms of the lowenergy expansion of the effective action, but since we are confident that there is a consistent quantum theory, such an algorithm should exist. The unknown 11d quantum theory is referred to as M theory." (Schwarz (1997) 12)

Die materierepräsentierenden offenen Strings koppeln, dem Horava-Witten-Szenario zufolge, nur an den beiden zehndimensionalen Universen (bzw. 9-Branen) an. Die Gravitonen können sich als Zustände geschlossener Strings frei bewegen. Es könnte also sein, dass eines der zehndimensionalen Universen unser gewöhnliches Materieuniversums ist, das zweite Universum hingegen die "Schattenwelt" der dunklen Materie, die mit unserem Universum nur über die Gravitation wechselwirkt. Siehe etwa Horava / Witten (1996) und Polchinski (1999). Ein älterer Vorläufer dieser Idee findet sich in Kolb et al. (1985).

130 Von einer ausgedehnten, flachen Raumzeit geht etwa das Antoniadis/ArkaniHamed/Dimopoulos/Dvali-Szenario aus. Siehe Antoniadis / Arkani-Hamed / Dimopoulos / Dvali (1998), Arkani-Hamed / Dimopoulos (2005), Arkani-Hamed / Dimopoulos / Dvali (1998) und (2000) sowie insbesondere Dvali (2004). Diesem Szenario zufolge verhält sich die Gravitation auf der materietragenden D3-Bran völlig anders als im materiefreien volldimensionalen Raum (wie Schall, der sich auf einer Metallplatte fortpflanzt) und bleibt deshalb tendenziell auf diese gebunden, ausser für sehr kleine und sehr grosse Distanzen. Wäre dem nicht so, so würde für die Gravitation nicht (für fast alle Grössenordnungen) das $1 / \mathrm{r}^{2}$-Gesetz gelten, sondern ein Gesetz mit einer sehr viel höheren inversen Potenz von $r$, was einerseits mit unserer Empirie nicht in Einklang zu bringen ist, andererseits aber auch dazu führen würde, dass die Energieund Längenskala, bei der die Gravitation die gleiche Stärke hat wie die anderen Wechselwirkungen, also die Planck-Skala, bei wesentlich geringeren Energie- und wesentlich grösseren Abstandswerten als für das geltende $1 / \mathrm{r}^{2}$-Gesetz läge:

"In three-dimensional space, gravity gets so fierce that quantum effects are important only on scales as small as the Planck length, $10^{-33} \mathrm{~cm}$. But if gravity depended more steeply on the radius, going as an inverse fourth power rather than an inverse square, then quantum effects would set in before one reached down to a radius as tiny as $10^{-33} \mathrm{~cm}$. The effective Planck length would no longer be 
Oder die zusätzlichen Dimensionen sind zwar ausgedehnt, aber im Gegensatz zu unserer phänomenologischen Raumzeit stark gekrümmt. ${ }^{131}$ Oder es gibt zwar eine Kompaktifizierung der überzähligen Dimensionen, aber nicht auf der Planck-Ebene.

\section{Kosmologische Szenarien}

Auf der Grundlage der Branweltszenarien wurden inzwischen verschiedene kosmologische Modelle entwickelt, die den Urknall als dynamischen Übergang erklären, die Singularität vermeiden, als den ihn die Allgemeine Relativitätstheorie behandelt, und meist in ein zyklisches kosmologisches Geschehen einbetten. Das am weitesten entwickelte dieser Modelle ist das ekpyrotische Szenario von Paul Steinhardt und Neil Turok: ${ }^{132} 133$

quite so tiny, and the amount of compression needed to create a mini-black hole would be less extreme than in ordinary three-dimensional space." (Rees (2001) 150)

"[...] with large or warped extra dimensions, one might encounter the fundamental Planck scale, and thus strong gravitational scattering, at the TeV scale."

(Giddings (2005) 4)

Für geringe Abstände würde sich aber auch im Antoniadis/Arkani-Hamed/Dimopoulos/Dvali-Szenario die Gravitation nicht nach dem $1 / \mathrm{r}^{2}$-Gesetz verhalten, sondern davon abweichen. Erste Ansätze zu einer empirischen Untersuchung dieser Möglichkeit laufen bereits. Eine solche Änderung hinsichtlich des $1 / \mathrm{r}^{2}$-Gesetzes für kleine Abstände könnte, wie manche vermuten, möglicherweise auch eine Erklärung für das Problem der beschleunigten kosmischen Expansion (siehe dazu Hedrich (2004)) liefern.

131 Von ausgedehnten, aber stark gekrümmten Zusatzdimensionen geht das Randall-Sundrum-Szenario (bzw. eine Variante davon) aus. Siehe etwa Randall / Sundrum (1999). Diesem Szenario zufolge wird die Gravitation durch die starke Krümmung der Zusatzdimensionen auf unsere phänomenologische vierdimensionale Raumzeit begrenzt. Dies gewährleistet wiederum die annähernde Gültigkeit des $1 / \mathrm{r}^{2}$-Gesetzes.

132 Siehe etwa Steinhardt / Turok (2002) und (2002a), Turok / Steinhardt (2002) und (2005), Khoury et al. (2001), Quevedo (2002) sowie Brax / Bruck (2003).

133 Ein weiterer Ansatz zur Erklärung des Urknalls ist Gabriele Venezianos PräUrknall-Modell. Dieses vermeidet die Singularität infolge der Stringdynamik und ihrer im Rahmen der T-Dualität deutlich werdenden minimalen Länge. Siehe etwa Veneziano (1998) und (2004) sowie Gasperini / Veneziano (2003). 
"We refer to our proposal as the 'ekpyrotic universe', a term drawn from the Stoic model of cosmic evolution in which the universe is consumed by fire at regular intervals and reconstituted out of this fire, a conflagration called ekpyrosis." (Khoury et al. (2001) 3f)

Der Urknall wird im ekpyrotischen Szenario als Kollision parallel liegender Branen gedeutet. ${ }^{134}$ Die Flachheit der Raumzeit wird als Resultat des Zustandes der Branen vor der Kollision erklärt, so dass das ekpyrotische Szenario ohne eine inflationäre Expansionsphase auskommt und insofern als Alternative zum Inflationären Szenario in der Kosmologie angetreten ist: ${ }^{135}$

"[...] rather than introducing superluminal expansion to resolve the horizon and flatness problems, the ekpyrotic model relies on the assumption that the universe began in an empty, quasi-static BPS state which lasted an exponentially long time prior to the beginning of the hot big bang phase." (Khoury et al. (2001) 6)

Die Festlegung der spezifischen Parameter, die unser Universum bestimmen, erfolgt im ekpyrotischen Szenario über Mechanismen der dynamischen Symmetriebrechung während der Brankollision:

"This transition can change the gauge group on the visible brane. [...] Furthermore, the number of light families of quarks and leptons on the visible brane may change during the transition. [...] Hence, the brane collision is not only responsible for initiating the expansion of the universe, but also for spontaneously breaking symmetries and for producing all of the quarks and leptons." (Khoury et al. (2001) 8)

Die Brankollision könnte, dem ekpyrotischen Szenario zufolge, ein zyklischer Prozess sein. Es wäre denkbar, dass sich die Branen nach der Kolli-

$134 \quad$ Weitere exotische kosmologische Modelle deuten den Urknall als Bran-Zerfall bzw. als Bran-Antibran-Annihilierung.

135 Hinsichtlich des Spektrums der Anisotropien in der Mikrowellenhintergrundstrahlung unterscheidet sich das ekpyrotische Szenario in seinen Vorhersagen von denen des Inflationären Szenarios (vgl. etwa Linde (1984) und (1990)), so dass sich in Zukunft mit steigender Genauigkeit der Messung dieser Anisotropien die Möglichkeit für empirische Tests ergeben sollte. Auch im Rahmen von Gravitationswellen-Detektorexperimenten sollten sich auf lange Sicht Überprüfungsinstanzen für die Vorhersagen des ekpyrotischen Szenarios ergeben. 
sion erst einmal gegenseitig abstossen, um sich dann schliesslich wieder anzunähern, so dass es zu einer weiteren Kollision kommt. ${ }^{136}$

136 Neben den kosmologischen Szenarien gibt es, verbunden mit dem Stringansatz, eine ganze Reihe von Detailvorschlägen mit kosmologischer Relevanz. So könnte sich beispielsweise die dunkle Energie, die für die beschleunigte Expansion des Kosmos verantwortlich gemacht wird, als Effekt des Dilaton-Feldes darstellen. Siehe hierzu Lu / Huang / Fang / Zhang (2004). 
